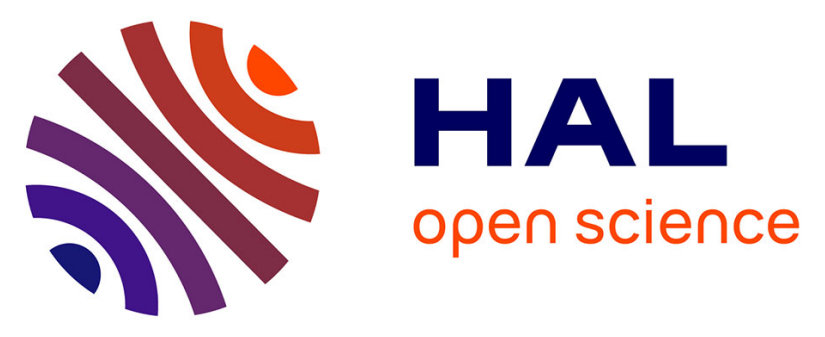

\title{
Evolution of the Cook Ice Cap (Kerguelen Islands) between the last centuries and 2100 ce based on cosmogenic dating and glacio-climatic modelling
}

Deborah Verfaillie, Joanna Charton, Irene Schimmelpfennig, Zoe Stroebele, Vincent Jomelli, François Bétard, Vincent Favier, Julien Cavero, Etienne Berthier, Hugues Goosse, et al.

\section{To cite this version:}

Deborah Verfaillie, Joanna Charton, Irene Schimmelpfennig, Zoe Stroebele, Vincent Jomelli, et al.. Evolution of the Cook Ice Cap (Kerguelen Islands) between the last centuries and 2100 ce based on cosmogenic dating and glacio-climatic modelling. Antarctic Science, 2021, pp.1-17. $10.1017 /$ S0954102021000080 . hal-03226107

\section{HAL Id: hal-03226107 https://hal.science/hal-03226107}

Submitted on 14 May 2021

HAL is a multi-disciplinary open access archive for the deposit and dissemination of scientific research documents, whether they are published or not. The documents may come from teaching and research institutions in France or abroad, or from public or private research centers.
L'archive ouverte pluridisciplinaire HAL, est destinée au dépôt et à la diffusion de documents scientifiques de niveau recherche, publiés ou non, émanant des établissements d'enseignement et de recherche français ou étrangers, des laboratoires publics ou privés. 
Evolution of the Cook Ice Cap (Kerguelen Islands) between the last centuries and $2100 \mathrm{CE}$ based on cosmogenic dating and glacio-climatic modelling

Deborah Verfaillie ${ }^{\mathrm{a}^{*}}$, Joanna Charton ${ }^{\mathrm{b}}$, Irene Schimmelpfennig ${ }^{\mathrm{b}}$, Zoe Stroebele ${ }^{\mathrm{c}}$, Vincent Jomelli $^{\mathrm{b}}$, François Bétard ${ }^{\mathrm{d}}$, Vincent Faviere ${ }^{\mathrm{e}}$ Julien Cavero ${ }^{\mathrm{c}}$, Etienne Berthier ${ }^{\mathrm{f}}$, Hugues Goosse ${ }^{\mathrm{a}}$, Vincent Rinterknecht ${ }^{\mathrm{b}}$, Claude Legentil ${ }^{\mathrm{c}}$, Raphaelle Charrassin ${ }^{\mathrm{f}}$, Georges Aumaître ${ }^{\mathrm{b}, * *}$, Didier L. Bourlès $^{\mathrm{b}, * *}$, Karim Keddadouche $\mathrm{b}^{\mathrm{b}, * *}$

${ }^{a}$ Earth and Life Institute, Université catholique de Louvain, Louvain-la-Neuve, Belgium

${ }^{b}$ Aix Marseille Univ, CNRS, IRD, INRAE, Coll France, UM 34 CEREGE, Aix-en-Provence, France

${ }^{c}$ Université Paris 1 Panthéon-Sorbonne, CNRS Laboratoire de Géographie Physique, Meudon, France

${ }^{d}$ Université de Paris, UFR Géographie, Histoire, Économie et Sociétés (GHES), Laboratoire PRODIG, UMR CNRS

8586, Paris, France

${ }^{e}$ Univ. Grenoble Alpes, IGE, CNRS, Grenoble, France

${ }^{f}$ LEGOS, Université de Toulouse, CNES, CNRS, IRD, UPS, Toulouse, France

**Aster Team

*Corresponding author: Deborah Verfaillie: ORCID $\underline{\text { 0000-0003-0603-0780 }}$

deborah.verfaillie@gmail.com

Joanna Charton: $\underline{0000-0002-2625-8793}$

Irene Schimmelpfennig: $\underline{0000-0001-8145-9160}$

Zoe Stroebele: $\underline{0000-0003-2048-6143}$

Vincent Jomelli: $\underline{\text { 0000-0002-4512-5216 }}$

François Bétard: 0000-0002-6309-3414

Vincent Favier: 0000-0001-6024-9498

Julien Cavero: 0000-0003-2158-3420

Etienne Berthier: 0000-0001-5978-9155

Hugues Goosse: 0000-0002-5438-3612

Vincent Rinterknecht: $\underline{0000-0002-5410-2075}$

Didier L. Bourlès: 0000-0001-5991-6126 


\section{Abstract (200 words max.)}

The Cook Ice Cap (CIC) on the sub-Antarctic Kerguelen Islands recently experienced extremely negative surface mass balance. Further deglaciation could have important impacts on endemic and invasive fauna and flora. To put this exceptional glacier evolution into a multi-centennial-scale context, we refined the evolution of the CIC over the last millennium, investigated the associated climate conditions, and explored its potential evolution by $2100 \mathrm{CE}$. A glaciological model, constrained by cosmic ray exposure dating of moraines, historical documents and recent direct mass balance observations, was used to simulate the ice cap extents during different phases of advance and retreat between the last millennium and $2100 \mathrm{CE}$. Cosmogenic dating suggests glacial advance around the early Little Ice Age (LIA), consistent with findings from other sub-Antarctic studies, and the rather cold and humid conditions brought by the negative phase of the Southern Annular Mode (SAM). This study contributes to our currently limited understanding of palaeoclimate for the early LIA in the southern Indian Ocean. Glaciological modelling and observations confirm the recent decrease in CIC extent linked to the intensification of the SAM. Although affected by large uncertainties, future simulations suggest a complete disappearance of CIC by the end of the century.

Keywords: sub-Antarctic islands, glacial fluctuations, moraines, in situ cosmogenic chlorine-36 dating, degree-day glaciological model, future projections 


\section{Introduction}

The Kerguelen Islands, discovered on 12 February 1772 by the French navigator Yves Joseph Kerguelen de Tremarec, covers an area of approximately $7200 \mathrm{~km}^{2}$ in the southern Indian Ocean in the sub-Antarctic zone (Fig. 1). This archipelago constitutes one of the five districts of the French Austral and Antarctic Territories (Terres Australes et Antarctiques Françaises, TAAF). It consists of a main island called Grande Terre, surrounded by more than 300 islets, most of which are very close to the main island. The scientific station of Port-aux-Français (PAF) built in the 1950s is located on the eastern part of Grande Terre.

The Kerguelen Islands feature many glaciers in different parts of the archipelago. Small glaciers are present in the north on the Presqu'île de la Société de Géographie (Fig. 1). To the west, the Cook Ice Cap (CIC) culminates at $1049 \mathrm{~m}$ above sea level (a.s.1.) and in 2020 covers about 400 $\mathrm{km}^{2}$. It has about fifteen outlet glaciers, including the largest French glacier, Ampere Glacier, on its southeastern slope. It was glaciologically monitored in the 1970s (e.g., Poggi, 1977; Vallon, 1977a, 1977b) and again between 2010 and 2013 using stake measurements to determine its mass balance (Verfaillie et al., 2015; Favier et al., 2016). Further south, some twenty small glaciers cover the summits of the Rallier du Baty Peninsula and the slopes of Mount Ross, the highest peak in the archipelago (1850 $\mathrm{m}$ a.s.1.).

Moreover, the Kerguelen Islands are known to be home to various endemic plants such as the Kerguelen cabbage (Pringlea antiscorbutica) as well as a world-renowned wealth of fauna. Kerguelen is home to the largest population of king penguins (Aptenodytes patagonicus) in the world (more than 100,000 pairs), one of the largest colonies of wandering albatross (Diomedea exulans) and other birds across the austral region, as well as a very large number of fur seals and elephant seals (https://taaf.fr/en/presentation-of-the-territories/). These populations of extraordinary plants and animals have motivated the creation of strict and semi-strict nature reserves and, on a larger scale, the creation in the near future of a national park for the conservation of these endemic species. Unfortunately, the archipelago has been invaded by a large number of rapidly developing invasive species (rabbits, rats, reindeer, dandelion, etc.), most of which were introduced during the last century (e.g., Lesel, 1967 ; Chapui et al., 2004 ; 
Frenot et al., 2005). Glaciers are the last "barrier" against the colonisation of almost the entire archipelago by these invasive species. However, glacier mass balance has been extremely negative in recent years, primarily due to atmospheric drying on the Kerguelen Islands caused by a shift of the storm tracks to more southerly latitudes (Favier et al., 2016). The latter was induced by an intensification of the Southern Annular Mode (SAM), one of the most important climate features of the Southern Hemisphere high latitudes (e.g., Abram et al., 2014). Mass balance values measured for the whole CIC between 2000 and 2010 are $-1.59 \pm 0.19 \mathrm{~m}$ water equivalent per year (w.e. $\mathrm{a}^{-1}$, Favier et al., 2016). Taken individually, Ampere Glacier experienced even more negative values of $-2.60 \pm 0.30 \mathrm{~m}$ w.e. $\mathrm{a}^{-1}$ (Favier et al., 2016). These extreme surface mass balance values, among the most negative worldwide documented over this period of time, are causing significant thinning of the ice cap. Thinning values during the 2000 s of about $0.4 \pm 0.1 \mathrm{~m} \mathrm{a}^{-1}$ were measured right up to the summit of the ice cap (Favier et al., 2016), while thinning close to the front of Ampere glacier was in the order of $10 \mathrm{~m} \mathrm{a}^{-1}$. The glacier front retreated $2.8 \mathrm{~km}$ between 1963 and 2003 (Berthier et al., 2009), and an extra $1.5 \mathrm{~km}$ from 2003 to present. This recent glacier retreat implies the opening up of new sub-aerially exposed areas for endemic and invasive species to colonise. But will endemic species be able to compete with invasive species during this colonisation phase? If we want to understand and predict the effect of the ice cap wastage on the current and future (by the end of the 21 st century) colonisation of the archipelago by invasive species, we first need to contextualise the ice cap evolution over a period in the past that was characterised by significant climate and glacier fluctuations. The last millennium is particularly suited for this experiment, due to the occurence of the so-called Little Ice Age (LIA) between around 1400 and $1870 \mathrm{CE}$ (Perren et al., 2020). The LIA corresponds to a period of the Earth's history that was globally $\sim 0.5^{\circ} \mathrm{C}$ colder than the end of the 20th century (Solomina et al., 2015). This cooling was recorded through pronounced re-advances of mountain glaciers in many parts of the Northern Hemisphere; glacial evidence of the LIA in the Southern Hemisphere is, however, more seldom and less clear (e.g., Mann, 2002; Neukom et al., 2014; Solomina et al., 2015).

Downstream of the current front of Ampere glacier, several moraines have been preserved and mapped (Frenot et al., 1997; Jomelli et al., 2017). The outermost moraine was dated using the 
chlorine-36 $\left({ }^{36} \mathrm{Cl}\right)$ cosmic ray exposure (CRE) method (Jomelli et al., 2017), in situ-produced ${ }^{36} \mathrm{Cl}$ being the most suitable cosmogenic nuclide given Kerguelen's widespread volcanic lithologies. Although the uncertainties associated with the mean age of this moraine are too large to robustly assign its emplacement during the LIA, this mean age attests to a significant extension over the last millennium. To put the observed evolution of Ampere Glacier and the CIC over the last decades into a multi-centennial-scale context, the objective of this paper is to refine the evolution of the CIC and Ampere Glacier over the last millennium, investigate the associated climate conditions during this time, and explore the potential evolution of CIC up to the end of the 21 st century based on available future climatic scenarios. To this end, a glaciological model, constrained by CRE moraine dating, historical documents and recent direct mass balance observations, is used here to propose a mapping of different phases of extension between the last millennium and $2100 \mathrm{CE}$. 


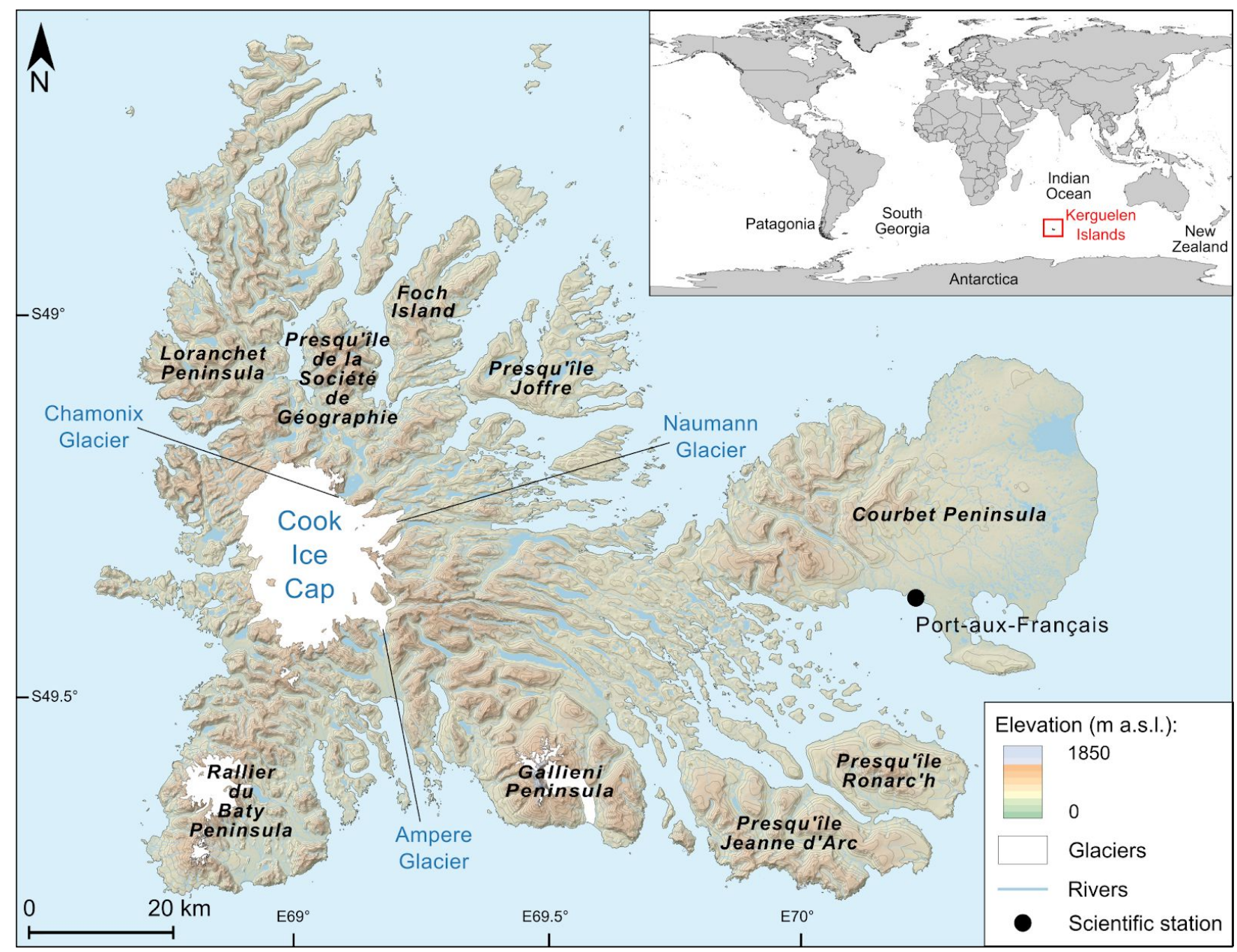

Fig. 1. Map of the Kerguelen Islands and the locations of the glaciers investigated and mentioned in this study. Inset shows the location of the archipelago in the sub-Antarctic region (Digital Elevation Model from lpdaac.usgs.gov/products/srtmgl1v003/, glacier outlines from the Global Land Ice Measurement from Space (GLIMS) database; Raup et al., 2007).

\section{Study area}

The Kerguelen Islands (Fig. 1) represent the emerged part of the Kerguelen submarine volcanic plateau, which appeared about 40 million years ago. At the beginning of the 20th century, aboard the Charcot, Raymond Rallier du Baty explored the archipelago. A few years later, the French geologist Edgar Aubert de la Rüe and his wife Andrée began research on the geology and 
geography of the Kerguelen Islands. The geologist probably made the first description of glacial forms and deposits observed on the archipelago. He described the presence of numerous erratic boulders and identified two morainic belts, one located in the southern part of the archipelago on the Rallier du Baty Peninsula near Baie de la Mouche and the other in the eastern part of the archipelago north of the Jeanne d'Arc Peninsula, both of which he attributed to the Last Glacial Maximum (Aubert de la Rüe, 1932). Later in the 1960s, Jacques Nougier conducted a detailed geological and geomorphological survey of the Kerguelen Islands, with the editing of a 1:200,000-scale geological reconnaissance map (Nougier, 1970). As a volcanic archipelago related to a hotspot beneath the Antarctic plate (Kerguelen hotspot), the islands are geologically dominated by Tertiary flood basalts ("Basalte des Plateaux") that occupy more than $80 \%$ of the area. Other types of volcanic rocks are locally present, such as trachytes, basanites and phonolites, e.g. around the Mount Ross strato-volcano (Gallieni Peninsula), together with granitoids in the volcano-plutonic complex of Rallier du Baty. Although no eruptive activity has been recorded in historic times, active fumaroles can be observed in the southwest part of Grande-Terre island in relation to youthful subglacial eruptive centers and Holocene trachytic lava flows (Ballestracci and Nougier, 1984). Beyond the detailed geological descriptions he made in his thesis, Nougier (1970) also provided some geomorphological and glaciological observations which were consistent with Aubert de la Rüe's observations in the previous decades. He described and mapped many systems of lateral and frontal moraines that he attributed to the LIA, and calculated simple surface indices showing the extent of glacier recession between the 1930s and 1960s. Other historical sources attest to larger glacier extents in the last century (e.g., Aubert de la Rüe, 1967; Durand de Corbiac, 1970), especially on the eastern slope of the ice cap (Fig. 2). 

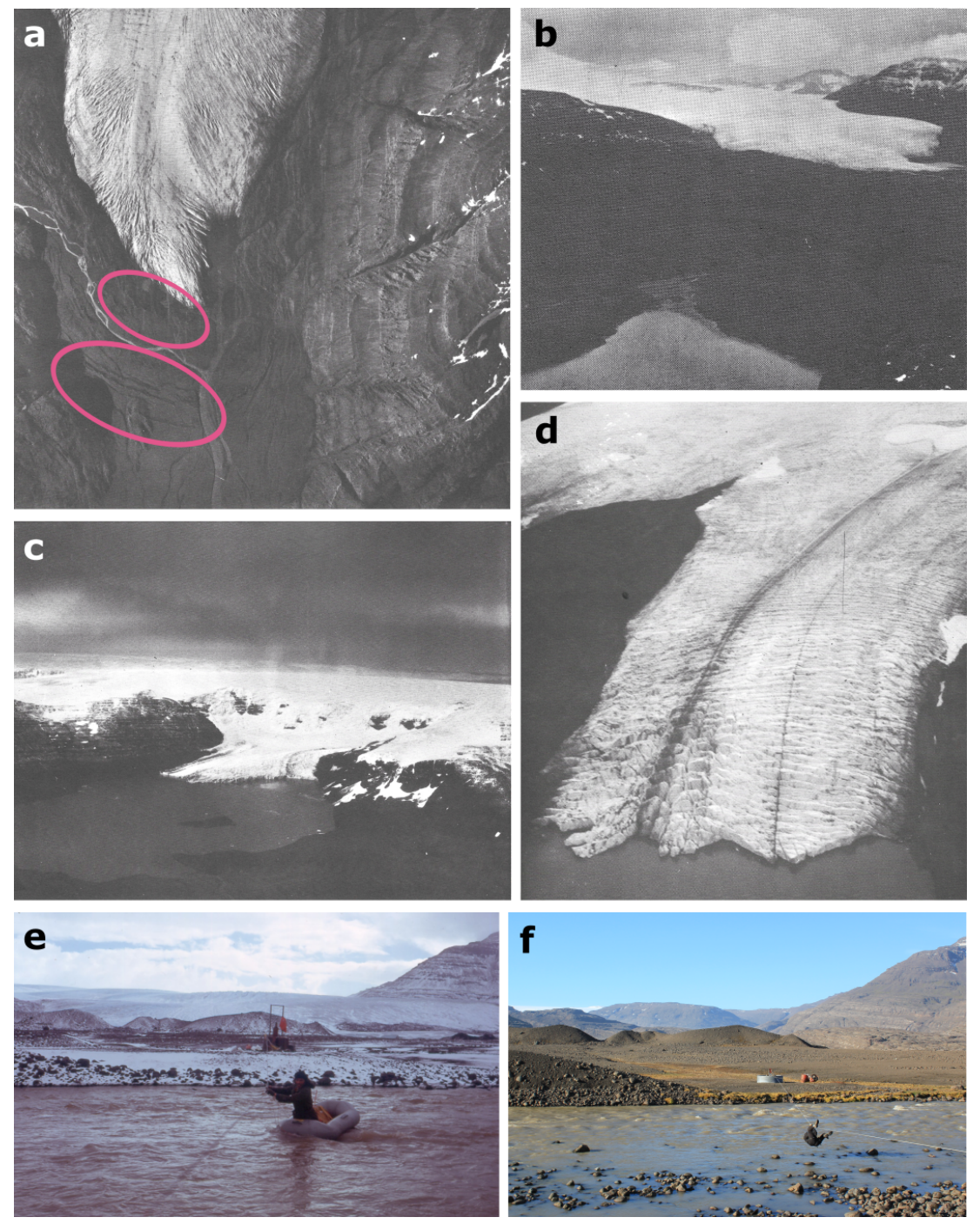

Fig. 2. Old and recent photographs of outlet glaciers of the CIC from Nougier (1970), Durand de Corbiac (1970) and this study. a. Vertical photograph (1/24,000 scale) of Ampere Glacier taken by Bauer in the austral summer of 1962-1963, with several morainic belts (circled in pink) visible below the glacier front. b. Ground photograph of Ampere Glacier taken by Nougier from the location of Lac Jaune between 1961 and 1965. c-d. Aerial photographs of Chamonix (c) and Naumann (d) Glaciers, located on the eastern slope of CIC, taken by Frölich in the austral summer of 1965-1966. e-f. Ground photographs taken from the same spot in front of Ampere Glacier in 1975 by P. Bois (e) and in 2013 by V. Rinterknecht (f), showing moraines closest to the current front of Ampere Glacier. Comparing these two photographs also highlights the dramatic shrinkage of the glacier during this 40 -year period.

The PAF weather station, set up in the 1950s (Fig. 1), provides one of the longest meteorological time series at this latitude of the Southern Hemisphere. Climate on the Kerguelen Islands is 
oceanic. The average annual temperature is $4.5^{\circ} \mathrm{C}$ with a low amplitude of about $6^{\circ} \mathrm{C}$. In summer, the average temperature is around $8^{\circ} \mathrm{C}$, while it is about $2^{\circ} \mathrm{C}$ in winter. The maxima rarely exceed $20^{\circ} \mathrm{C}$, while minima rarely reach values below $-10^{\circ} \mathrm{C}$. Precipitation, mainly from western lows, is around $800 \mathrm{~mm} \mathrm{a}^{-1}$ at PAF but exceeds $3000 \mathrm{~mm} \mathrm{a}^{-1}$ in the west near the CIC due to the marked foehn effect (Verfaillie et al., 2015, 2019; Favier et al., 2016).

\section{Methods}

A set of field-based and laboratory analyses combined with a glaciological model was performed in order to characterise the different phases of CIC extensions between the last millennium and $2100 \mathrm{CE}$. The methods are presented below into four subsections, describing the glacier extent modelling (for past extents and for future extents), how the past extents are constrained chronologically and spatially, the past climate scenarios derived from the modelling, and the future climate scenarios.

\section{Glacier extent modelling}

The extension of the CIC and the outlet glaciers was simulated using a positive degree-day glaciological model combined with a cellular automaton applied to a Digital Elevation Model (DEM), which allows the 3D simulation of the advance or retreat of a glacier as a function of altitude. This glaciological model has been successfully applied several times under different geomorphological and climatic conditions (Blard et al., 2007; Jomelli et al., 2011; Biette et al., 2018; Protin et al., 2019).

The model works by estimating accumulation and ablation on the glacier surface under set climatic conditions. Accumulation is calculated as a function of daily precipitation, a rain/snow limit temperature (here $1^{\circ} \mathrm{C}$ ), and daily temperatures. Ablation is calculated as a function of two melting parameters (or degree-day factors which represent the daily volume of snow and ice melted when the temperature is positive) and monthly temperatures. Glacier melting occurs when air temperature $1-2 \mathrm{~m}$ above the glacier surface is above the melting point $\left(0^{\circ} \mathrm{C}\right)$. The total 
melt over a period of time at some point on the glacier is therefore proportional to the sum of daily average positive temperatures at the same point, i.e. the positive degree day total. The difference between accumulation and ablation generates an annual surface or climatic mass balance associated with an equilibrium line. The cellular automaton applied to the 2009 DEM (125 m resolution) from Berthier et al. (2009) then simulates the past and future extension of the CIC.

The rain/snow limit temperature, the air temperature gradient and the melting parameters were calibrated from meteorological and mass and energy balance measurements carried out on the surface of Ampere Glacier between 2010 and 2014 (Verfaillie et al., 2015; Favier et al., 2016), and considered time-invariant. Eight different temperature gradients were computed for eight sectors corresponding to the glacier azimuth (every $45^{\circ}$ ) and considered constant with elevation, following Favier et al. (2016). Precipitation was also calibrated depending on elevation, following the relationship from Favier et al. (2016). Palaeo-extents documented from moraine records and old documents were used to validate the glaciological model in order to better constrain the future extents. Simulation of past glacier extents (early LIA, 1963 and 2009) follow the methods described in Favier et al. (2016). One should note that this model was not designed to simulate transient glacial states but rather pseudo-equilibrium states on decadal-to-centennial timescales.

\section{Chronological and spatial constraints to simulate past extents}

There are few sources available to map the past glacial extents of the Kerguelen Islands. For the CIC, Berthier et al. (2009) used the 1:200,000 geological reconnaissance map drawn up in 1967

by the National Geographic Institute (Institut Géographique National, IGN) and a Landsat satellite image from 2001. The IGN initial 1:200,000 cartographic product, the first modern topographic map of the Kerguelen Islands, is based on an aerial survey carried out from 1963 to 1966 during various IGN/TAAF campaigns on board Alouette II helicopters provided by the French Air Force. The two inventories from 1963-1966 and 2001 are available in the Global Land Ice Measurements from Space database (http://www.glims.org/; Raup et al., 2007). Glacial extents in 1963 and 2009 were then vectorised from two other sources to provide more data. 
Firstly, we used a 1:100,000 version (three sheets) of the IGN geological reconnaissance map, enriched with toponymy (Durand de Corbiac, 1970). Compared to this earlier map, the 1:100,000 document has an improved resolution allowing to display smaller topographic features. For example, the nunatak of Dulong, in the southern part of the CIC, which does not appear on the 1:200,000 sheet, appears on the 1:100,000 version. Geo-referencing of these three sheets involved adding more control points to make it consistent with the 1:200,000 sheet. For this purpose, we used the high-resolution coastline produced by the Hydrographic and Oceanographic Service of the French Navy as a reference. Secondly, we vectorised an additional glacial extension using a SPOT 2009 image of $5 \mathrm{~m}$ resolution acquired in good weather conditions. A complementary MODIS image at $250 \mathrm{~m}$ resolution is also available in 2009 from Verfaillie et al. (2015). These various cartographic and satellite sources therefore provide a map of the glacial extensions of the Cook Ice Cap in 1963 (between 1963 and 1966 depending on the area photographed), 2001 and 2009 (Fig. 3).

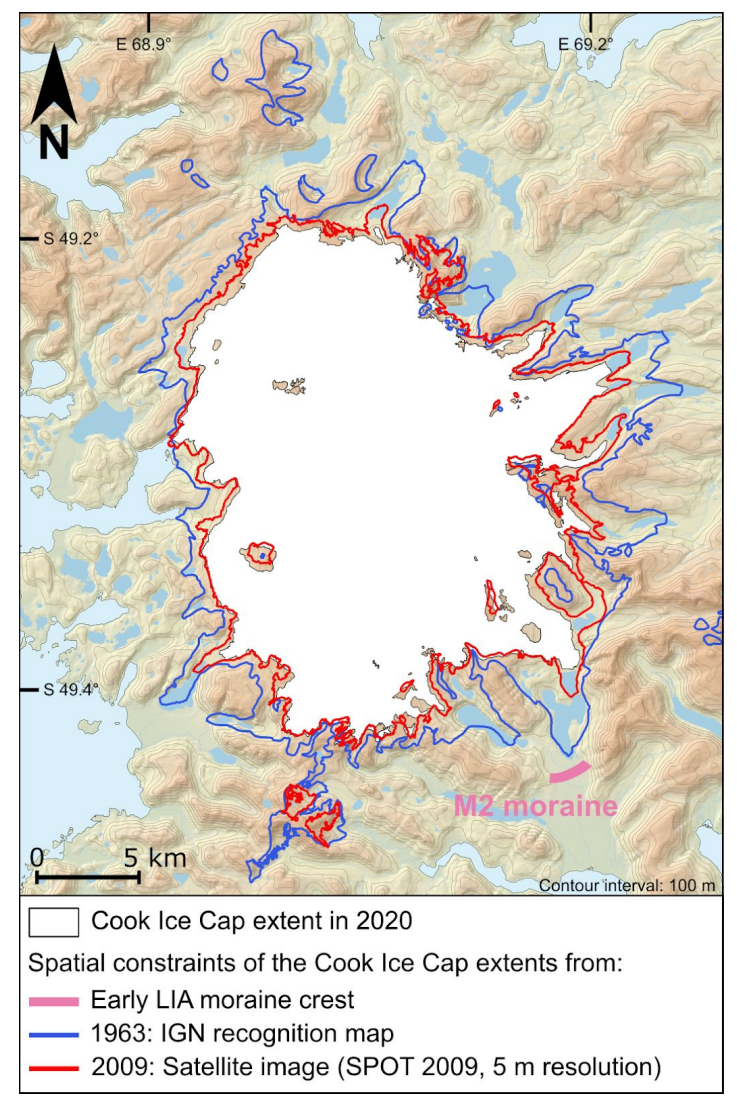


Fig. 3. Chronological and spatial constraints for the extents of the CIC for the early LIA, 1963 and 2009. The CIC extent in 2020 was derived from Pléiades satellite images acquired through the Pléiades Glacier Observatory (PGO) program. Digital Elevation Model from lpdaac.usgs.gov/products/srtmgl1v003/.

For glacial extents that pre-date the instrumental records, the glaciological model and the cellular automaton were constrained with glacial landforms, which are ice-marginal moraines. The IGN map shows moraines east of the ice cap, most of them located between a few hundred metres or a few kilometres from the current glacier front. Similar sequences of glacial deposits are also present on proglacial margins of other glaciated massifs of the archipelago, such as on Rallier du Baty Peninsula, on the Presqu'île de la Société de Géographie and on Gallieni Peninsula (Fig. 1). The Ampere valley, located south-east of the ice cap (Fig. 1), with its six large moraines mapped on the IGN map is probably the best site in the Kerguelen Islands to investigate glacier evolution during the last millennium. Almost 30 years ago, Frenot et al. (1993) proposed the first chronological estimation of their deposition during the LIA, based on radial growth of Azorella selago dating technique. In addition, this set of ice-marginal moraines, which are not a common feature at the base of CIC outlet glaciers mostly due to off-shore deposition, are well-preserved and relatively easy to access. The furthest downstream M1 moraine, located at $\sim 7 \mathrm{~km}$ from the current ice front of Ampere Glacier, was dated by Jomelli et al. (2017) using ${ }^{36} \mathrm{Cl} \mathrm{CRE}$ dating. Five rock surface samples collected from boulders on M1 moraine, had an arithmetic mean age and standard deviation of $700 \pm 320 \mathrm{yr}$ (corresponding to $1310 \pm 320 \mathrm{CE}$; Jomelli et al., 2017). To corroborate this age, potentially reduce its uncertainty and add further constraints to the glacier fluctuations within the last millennium, we collected five new samples during a field campaign in 2017-2018. Using a hammer and chisel, two new samples (MO-18 and -19) were extracted from the uppermost $\sim 3-4 \mathrm{~cm}$ surface of flat boulders embedded in M1 moraine (Fig. 4). Three other samples (MO-14, -15 and -16) were taken from M2 moraine, located $200 \mathrm{~m}$ upstream of M1 (Fig. 4). The geographic coordinates were measured using a handheld Garmin GPS, while the geometry of the surrounding horizon was determined using a compass and a clinometer for the calculation of the topographic shielding factor. All detailed sample information is shown in Table I. The five new samples collected on the archipelago were shipped to the CEREGE laboratory in Aix-en-Provence, France, where the basaltic whole rock samples 
were prepared for in situ-produced ${ }^{36} \mathrm{Cl} \mathrm{CRE}$ dating, following the same methods as those described in the online Supplemental material of Charton et al. (2020). The chemical compositions of the bulk rocks and the chemically-treated sample fractions, which are needed to compute the exposure ages, are listed in Tables II and III. The resulting individual ${ }^{36} \mathrm{Cl}$ ages are presented in Table IV with their $1 \sigma$ uncertainties and their analytical uncertainties in brackets. In the main text and in the figures, the individual ages are indicated with their analytical uncertainties to allow internal comparison between the calculated ages. Statistical populations were determined in accordance with glacial landforms and checked by a $\chi^{2}$ test in order to identify outliers. For each moraine sample population, we present here mean ages weighted by their relative uncertainties instead of arithmetic mean ages, as done in Jomelli et al. (2017), thus increasing significance on the analytically most precise results. The weighted means are reported with their full uncertainty in Table IV, with results for each age population from the calculation of the weighted error (given in brackets in Table IV) added to the analytical and production rate uncertainties by quadrature propagation. This allows comparing the results with other palaeo-climatic records.

Table I - Geographic sample locations, topographic shielding factors and sample thicknesses.

\begin{tabular}{|c|c|c|c|c|c|c|}
\hline $\begin{array}{c}\text { Sample } \\
\text { Name }\end{array}$ & $\begin{array}{c}\text { Latitude } \\
\left({ }^{\circ} \mathrm{S}\right)\end{array}$ & $\begin{array}{c}\text { Longitude } \\
\left({ }^{\circ} \mathbf{E}\right)\end{array}$ & $\begin{array}{c}\text { Elevation } \\
(\mathbf{m})\end{array}$ & $\begin{array}{c}\text { Shielding } \\
\text { factor }\end{array}$ & $\begin{array}{c}\text { Thickness } \\
(\mathrm{cm})\end{array}$ & Studies \\
\hline \multicolumn{7}{|l|}{ Moraine M1 } \\
\hline Ker-M1-01 & 49.44482 & 69.19164 & 27 & 0.995 & 3 & Jomelli et al. (2017) \\
\hline Ker-M1-02 & 49.44481 & 69.19131 & 27 & 0.997 & 3 & Jomelli et al. (2017) \\
\hline Ker-M1-04 & 49.44463 & 69.18935 & 32 & 0.984 & 3 & Jomelli et al. (2017) \\
\hline Ker-M1-07 & 49.44442 & 69.18886 & 34 & 0.989 & 4 & Jomelli et al. (2017) \\
\hline MO-18 & 49.44468 & 69.19037 & 38 & 0.998 & 5 & This study \\
\hline MO-19 & 49.44468 & 69.19037 & 38 & 0.998 & 3 & This study \\
\hline \multicolumn{7}{|l|}{ Moraine M2 } \\
\hline MO-14 & 49.44284 & 69.19008 & 35 & 0.998 & 3 & This study \\
\hline MO-15 & 49.44252 & 69.18836 & 36 & 0.998 & 2 & This study \\
\hline MO-16 & 49.44252 & 69.18836 & 36 & 0.998 & 2 & This study \\
\hline
\end{tabular}


Table II - Chemical compositions of the bulk rock samples before chemical treatment. Analysis performed at the SARM-CRPG (Nancy, France) by ICP-OES (major elements), ICP-MS (trace element), atomic absorption (Li), colorimetry (B) and spectrophotometry (Cl).

\begin{tabular}{|c|c|c|c|c|c|c|c|c|c|c|c|c|c|c|c|c|c|c|c|}
\hline $\begin{array}{l}\text { Sample } \\
\text { Name }\end{array}$ & $\begin{array}{c}\mathrm{CaO} \\
\%\end{array}$ & $\begin{array}{c}\mathrm{K} 2 \mathrm{O} \\
\%\end{array}$ & $\begin{array}{c}\mathrm{TiO}^{2} \\
\%\end{array}$ & $\begin{array}{c}\mathrm{Fe} 2 \mathrm{O} \\
\%\end{array}$ & $\begin{array}{c}\mathrm{SiO2} \\
\%\end{array}$ & $\begin{array}{c}\mathrm{Na} 2 \mathrm{O} \\
\%\end{array}$ & $\underset{\%}{\mathrm{MgO}}$ & $\underset{\%}{\mathrm{Al2O} 3}$ & $\underset{\%}{\mathrm{MnO}}$ & $\begin{array}{c}\mathrm{P} 2 \mathrm{O} 5 \\
\%\end{array}$ & $\begin{array}{c}\mathrm{CO} 2 \\
\%\end{array}$ & $\begin{array}{c}\mathrm{Cl} \\
(\mathrm{ppm})\end{array}$ & $\begin{array}{c}\mathbf{L i} \\
(\mathrm{ppm})\end{array}$ & $\begin{array}{c}\mathrm{B} \\
(\mathrm{ppm})\end{array}$ & $\begin{array}{c}\mathrm{Sm} \\
(\mathrm{ppm})\end{array}$ & $\begin{array}{c}\text { Gd } \\
(\mathrm{ppm})\end{array}$ & Th (ppm) & $\mathbf{U}(\mathrm{ppm})$ & LOI \\
\hline \multicolumn{20}{|l|}{ M1 moraine } \\
\hline Ker-M1-01 & 10.74 & 0.44 & 2.74 & 13.01 & 47.24 & 2.51 & 3.54 & 12.74 & 0.17 & 0.31 & 3.38 & 29 & 3.6 & $<2$ & 5.97 & 6.04 & 1.95 & 0.39 & 0.31 \\
\hline Ker-M1-04 & 10.89 & 0.27 & 2.41 & 11.51 & 44.96 & 2.88 & 5.54 & 13.85 & 0.16 & 0.24 & 1.62 & 25 & 6.6 & 3.0 & 5.05 & 5.08 & 1.57 & 0.32 & 0.24 \\
\hline Ker-M1-07 & 4.78 & 1.42 & 2.63 & 11.13 & 63.83 & 2.20 & 2.02 & 9.10 & 0.10 & 0.34 & 0.68 & $<20$ & 23 & $<2$ & 6.41 & 6.21 & 2.56 & 0.46 & 0.34 \\
\hline MO-18 & 9.25 & 0.39 & 2.94 & 18.02 & 46.69 & 2.64 & 4.60 & 13.45 & 0.21 & 0.29 & 1.10 & 85 & 4.84 & 3.4 & 5.76 & 5.75 & 1.83 & 0.47 & 0.90 \\
\hline MO-19 & 5.16 & 2.09 & 2.18 & 16.70 & 54.58 & 3.48 & 2.41 & 12.81 & 0.20 & 0.69 & 0.89 & 53 & 12.2 & 4.7 & 12.95 & 12.08 & 6.05 & 1.43 & 0.00 \\
\hline \multicolumn{20}{|l|}{ M2 moraine } \\
\hline MO-14 & 7.92 & 0.64 & 3.48 & 23.71 & 46.20 & 2.74 & 4.06 & 11.72 & 0.26 & 0.37 & 0.86 & 99 & 4.51 & 4.2 & 7.20 & 7.08 & 2.68 & 0.60 & 0.00 \\
\hline MO- 15 & 8.23 & 0.89 & 3.59 & 15.09 & 49.55 & 2.83 & 4.23 & 12.71 & 0.20 & 0.44 & 0.20 & 120 & 3.75 & 3.8 & 8.26 & 7.80 & 3.05 & 0.67 & 1.72 \\
\hline MO-16 & 11.20 & 0.37 & 2.01 & 10.70 & 48.53 & 2.60 & 5.89 & 16.42 & 0.14 & 0.22 & 0.29 & 32 & 4.25 & 2.1 & 4.57 & 4.53 & 1.42 & 0.33 & 2.10 \\
\hline
\end{tabular}

\begin{tabular}{|c|c|c|c|c|c|c|c|c|c|c|c|}
\hline Sample Name & $\mathrm{CaO} \%$ & $\mathrm{~K}_{2} \mathrm{O} \%$ & $\mathrm{TiO}_{2} \%$ & $\mathrm{Fe}_{2} \mathrm{O}_{3} \%$ & $\mathrm{SiO}_{2} \%$ & $\mathrm{Na}_{2} \mathrm{O} \%$ & $\mathrm{MgO} \%$ & $\mathrm{Al}_{2} \mathrm{O}_{3} \%$ & $\mathrm{MnO} \%$ & $\mathrm{P}_{2} \mathrm{O}_{5} \%$ & LOI \\
\hline \multicolumn{12}{|l|}{ M1 moraine } \\
\hline Ker-M1-01 & $8.52 \pm 0.17$ & $0.48 \pm 0.07$ & $2.97 \pm 0.15$ & $9.64 \pm 0.19$ & $54.67 \pm 1.09$ & $2.93 \pm 0.29$ & $3.37 \pm 0.34$ & $13.79 \pm 0.28$ & $0.110 \pm 0.021$ & $0.110 \pm 0.015$ & 2.88 \\
\hline Ker-M1-02 & $5.34 \pm 0.11$ & $0.14 \pm 0.02$ & $3.08 \pm 0.15$ & $7.9 \pm 0.16$ & $72.2 \pm 1.4$ & $1.56 \pm 0.16$ & $2.64 \pm 0.26$ & $6.60 \pm 0.66$ & $0.140 \pm 0.028$ & < L.D. (0.10) & 0.73 \\
\hline Ker-M1-04 & $2.72 \pm 0.14$ & $1.28 \pm 0.06$ & $2.54 \pm 0.13$ & $11.26 \pm 0.23$ & $70.3 \pm 1.4$ & $1.77 \pm 0.18$ & $1.72 \pm 0.17$ & $6.71 \pm 0.67$ & $0.100 \pm 0.020$ & $0.040 \pm 0.004$ & 1.86 \\
\hline Ker-M1-07 & $8.60 \pm 0.17$ & $0.25 \pm 0.04$ & $2.83 \pm 0.14$ & $11.46 \pm 0.23$ & $52.57 \pm 1.05$ & $2.44 \pm 0.24$ & $5.76 \pm 0.12$ & $10.33 \pm 0.21$ & $0.150 \pm 0.030$ & $0.190 \pm 0.029$ & 5.73 \\
\hline MO-18 & $9.06 \pm 0.45$ & $0.42 \pm 0.10$ & $3.58 \pm 0.36$ & $14.16 \pm 0.28$ & $52.6 \pm 1.1$ & $2.68 \pm 0.27$ & $5.07 \pm 0.10$ & $11.65 \pm 0.23$ & $0.220 \pm 0.044$ & < L.D. $(0.10)$ & 0.05 \\
\hline MO-19 & $4.22 \pm 0.63$ & $2.06 \pm 0.21$ & $2.66 \pm 0.27$ & $9.17 \pm 0.92$ & $63.8 \pm 1.3$ & $3.59 \pm 0.36$ & $1.77 \pm 0.18$ & $12.19 \pm 0.24$ & $0.181 \pm 0.036$ & $<$ L.D. $(0.10)$ & 0.20 \\
\hline \multicolumn{12}{|l|}{ M2 moraine } \\
\hline MO-14 & $7.72 \pm 0.39$ & $0.71 \pm 0.14$ & $3.92 \pm 0.39$ & $14.73 \pm 0.02$ & $53.7 \pm 1.1$ & $2.92 \pm 0.29$ & $4.26 \pm 0.43$ & $11.59 \pm 0.23$ & $0.226 \pm 0.045$ & $<$ L.D. $(0.10)$ & 0.00 \\
\hline MO- 15 & $7.56 \pm 0.38$ & $0.89 \pm 0.18$ & $3.60 \pm 0.36$ & $13.83 \pm 0.28$ & $54.8 \pm 1.1$ & $2.73 \pm 0.27$ & $4.57 \pm 0.46$ & $11.38 \pm 0.23$ & $0.198 \pm 0.040$ & $<$ L.D. $(0.10)$ & 0.54 \\
\hline MO-16 & $11.25 \pm 0.23$ & $0.32 \pm 0.08$ & $3.02 \pm 0.30$ & $11.05 \pm 0.22$ & $52.3 \pm 1.0$ & $2.15 \pm 0.22$ & $6.17 \pm 0.12$ & $12.42 \pm 0.25$ & $0.170 \pm 0.035$ & $<$ L.D. $(0.10)$ & 0.67 \\
\hline
\end{tabular}

\section{Past climate scenarios}

For the oldest past extent considered here, the glaciological mass balance model combined with the simple ice flow dynamic model was then used to invert the palaeoclimate conditions (considering several temperature and precipitation scenarios) responsible for the stillstand or advance documented from the second outermost CRE-dated preserved moraine, associated with an estimate of the Equilibrium Line Altitude (ELA) and mass balance changes for the palaeo-glacial extent. To select the best temperature and precipitation scenario among the different available temperature-precipitation couples, we performed a comparison with the oldest temperature reconstruction in the region, the ERSSTv2 (Smith and Reynolds, 2004) data, over the 19th century. Although the CIC extent in the 19th century is unknown, the LIA is known to have terminated in many parts of the world in the 19th century, sometimes with maximum glacier extents (e.g., Mann, 2002; Neukom et al., 2014; Solomina et al., 2015). Therefore it is 
very likely that one of the nearby inner (undated) moraines was deposited during the 19th century, and the ERSSTv2 dataset is thus a good approximation of the temperature conditions that prevailed during the LIA. Once temperature was set, we determined the corresponding precipitation scenario from the temperature-precipitation couple that allowed us to reconstruct the early LIA extent of CIC.

Climatic conditions for 1963 were considered the same as observed over the period 1935-1962, which is the reference period in this study, corresponding to a period of relative glacier stability according to Favier et al. (2016). For 2009, the observed mean climate conditions of temperature and precipitation prevailing from 2000 to 2010 were considered.

\section{Future climate scenarios}

Previous studies have shown that most climate models have deficiencies in the Kerguelen region over the recent period (Favier et al., 2016; Verfaillie et al., 2019). More specifically, they are unable to accurately represent the amounts and intensity of precipitation in the region because of an incorrect representation of atmospheric circulation changes, e.g., those related to the Southern Annular Mode. In this study, we have selected the model that best simulates the observations in terms of precipitation amounts and temperature as input of the glaciological model, thereby giving the best surface mass balance estimates over the recent period (Verfaillie et al., 2019). The model is ACCESS1-3 (Commonwealth Scientific and Industrial Research Organisation, and Bureau of Meteorology, Australia) from the Coupled Model Intercomparison Project phase 5 (CMIP5, Taylor et al., 2012), forced here by the two available RCP climate change scenarios, RCP4.5 and RCP8.5 (Moss et al., 2010), over 2006-2100. We simulate the projected CIC extent in 2100 using 10 year-mean corrected temperature and precipitation outputs for the 2090-2100 period from this model, fed into the glaciological model. Indeed, in spite of a good agreement of ACCESS1-3 model outputs with reanalysis of mean summer temperature and annual specific humidity at $850 \mathrm{hPa}$ over the Southern Ocean (Verfaillie et al., 2009), the modelled temperature and precipitation at PAF still present large biases over the period 1950-2005. Therefore, the 
mean and the standard deviation of temperature and the mean precipitation were corrected. Corrected temperature ( $T_{A C C E S S}^{c o r r}$ ) for the present situation was performed as follows:

$$
T_{A C C E S S}^{c o r r}=\frac{T_{A C C E S S}-\overline{T_{A C C E S S}(2000)}}{\sigma\left(T_{A C C E S S}(2000)\right)} \times \sigma\left(T_{o b s}\right)+\overline{T_{o b s}},
$$

where $T_{A C C E S S}$ is the original daily temperature given by ACCESS1-3, $\overline{T_{A C C E S S}(2000)}$ and $\sigma\left(T_{A C C E S S}(2000)\right)$ are the mean and standard deviation of $T_{A C C E S S}$ over 1995-2005 and $\overline{T_{o b s}}$ and $\sigma\left(T_{o b s}\right)$ are the mean and the standard deviation of observed temperature over 2000-2010. The temperature biases were removed by comparing observations from 2000-2010 and modelled data from 1995-2005 because the model already displayed a significant warming over the end of the 20th century. Precipitation biases were removed by applying the ratio between the mean modelled precipitation over 1950-2005 and the mean observed precipitation over 2000-2010 to the daily modelled precipitation. This correction reproduces the precipitation amount observed over the period of 2000-2010. Mean modelled precipitation over 1950-2005 was chosen because ACCESS1-3 did not display any significant trend over this period.

For future simulations, the correction ratio for precipitation was kept constant, so that future precipitation changes only reflect the increase related to Clausius-Clapeyron processes already included in ACCESS1-3 modelling results (not the increase due to circulation changes, usually a weak contribution in the CMIP5 models). Future temperature biases were removed assuming that the correction of the standard deviation of ACCESS1-3 temperature remains constant with time. Since temperature increases with time, the correction needs to account for the difference between $T_{A C C E S S}$ and the mean temperature in the future, $T_{A C C E S S}(2100)$, as follows:

$$
T_{A C C E S S}^{c o r r}=\left(\frac{T_{A C C E S S} \overline{T_{A C C E S S}(2100)}}{\sigma\left(T_{A C C E S S}(2000)\right)} \times \sigma\left(T_{o b s}\right)+\overline{T_{o b s}}\right)+\left(\overline{T_{A C C E S S}(2100)}-\overline{T_{A C C E S S}(2000)}\right),
$$

where $\overline{T_{A C C E S S}(2100)}$ is the mean temperature over 2090-2100. In equation 2 , the first term allows $T_{A C C E S S}$ to conserve the standard deviation of observations in the $2000 \mathrm{~s}$, whereas the second term accounts for $T_{A C C E S S}$ warming between 2000 and 2100. 
The climatic trends given for the 21 st century by ACCESS1-3 for the RCP8.5 scenario (warming of $0.026^{\circ} \mathrm{C} \mathrm{a}^{-1}$ and precipitation increase of $2.13 \mathrm{~mm} \mathrm{a}^{-1}$, before bias correction of precipitation) are close to those given by the "mean model," defined as the average output of the 36 different models from CMIP5 (mean warming of $0.029^{\circ} \mathrm{C} \mathrm{a}^{-1}$, with a standard deviation of $0.009^{\circ} \mathrm{C} \mathrm{a}^{-1}$ and precipitation increase of $1.92 \mathrm{~mm} \mathrm{a}^{-1}$, with a standard deviation of $0.76 \mathrm{~mm} \mathrm{a}^{-1}$ ). The mean model is expected to exhibit weaker large-scale biases than most of the models taken individually. Assuming the consistent stationarity of large-scale biases from CMIP5 models (Krinner and Flanner, 2018), ACCESS1-3 will remain within the best models for Kerguelen in the future.

\section{Results}

Chlorine-36 ages from Ampere Glacier's moraines 


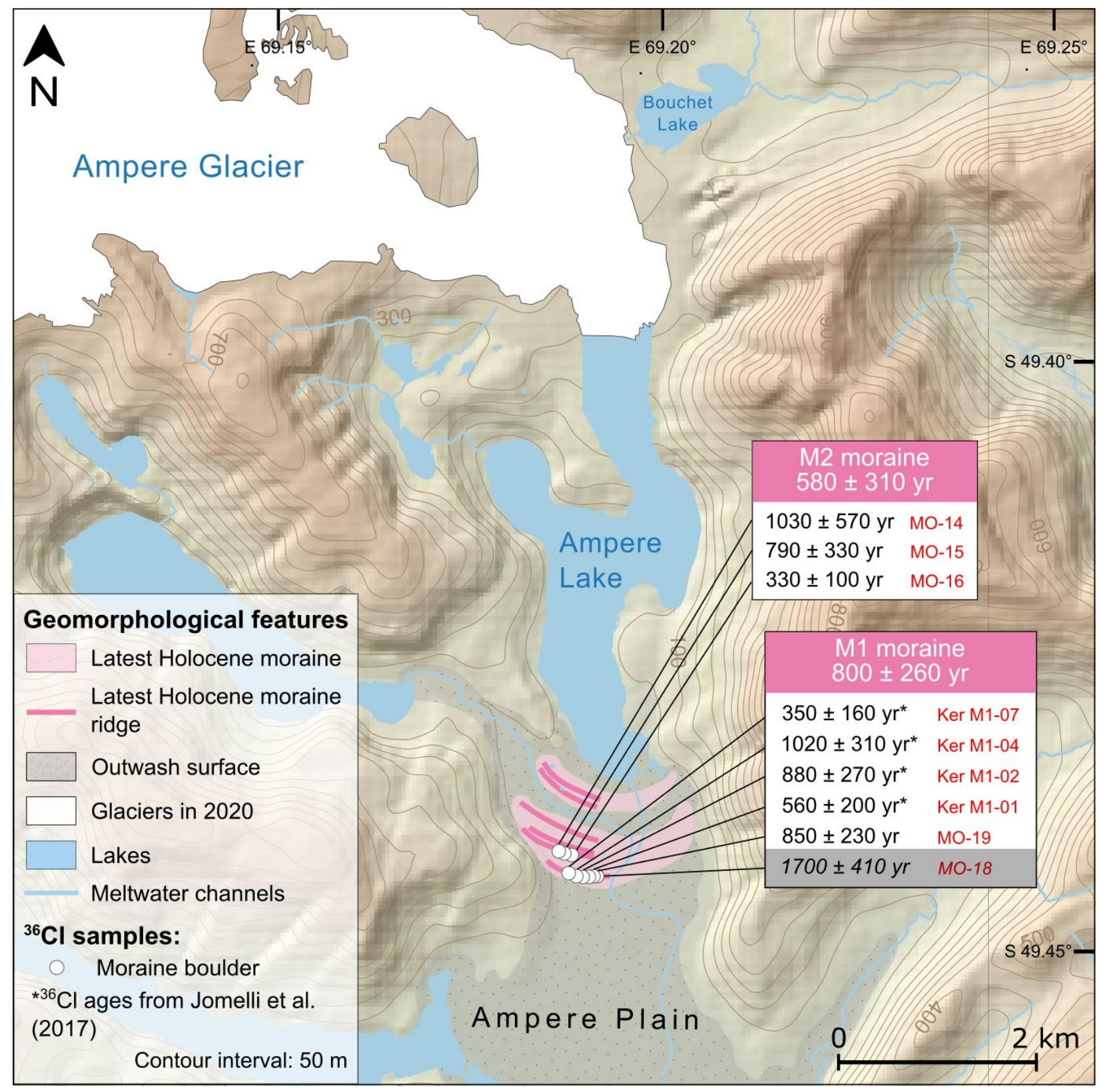

Fig. 4. Glacio-geomorphological map of Ampere Glacier on a 40 m resolution DEM (Digital Elevation Model from lpdaac.usgs.gov/products/srtmgl1v003/, glacier outlines were derived from Pléiades satellite images acquired through the Pléiades Glacier Observatory (PGO) program). White boxes show ${ }^{36} \mathrm{Cl}$ ages of individual moraine boulders with their inferred analytical uncertainties. The weighted mean ages of both moraines are shown in coloured boxes with their full uncertainties (i.e. weighted errors, analytical and production rate uncertainties). The sample highlighted in grey is rejected as an outlier (based on a $\mathrm{Chi}^{2}$ test) and therefore excluded from the moraine mean age and the discussion. 
The chlorine-36 ages at the base of Ampere Glacier span from $330 \pm 100$ to $1700 \pm 410$ years (Table IV, Fig. 4). The previously determined boulder ages on the outermost M1 moraine of 560 $\pm 200 \mathrm{yr}($ Ker M1-01), $880 \pm 270 \mathrm{yr}(-02), 1020 \pm 310 \mathrm{yr}(-04)$ and $350 \pm 160 \mathrm{yr}(-07)$ are complemented with ages from the two samples MO-18 and -19 , which are $1700 \pm 410$ and $850 \pm$ $230 \mathrm{yr}$, respectively. MO-18 was rejected as an outlier, probably because of prior exposure to cosmic rays. The remaining ages yield a weighted mean age and full uncertainty of $800 \pm 260 \mathrm{yr}$ $(n=5)$, corresponding to the year $1220 \pm 260$ CE. Chlorine-36 ages of MO-14, -15 and -16 , collected on Moraine M2 are $1030 \pm 570,790 \pm 330$ and $330 \pm 100 \mathrm{yr}$. M2 moraine weighted mean age and full uncertainty are $580 \pm 310 \mathrm{yr}(\mathrm{n}=3)$, corresponding to the year $1440 \pm 310 \mathrm{CE}$.

\begin{tabular}{|c|c|c|c|c|c|c|c|c|}
\hline $\begin{array}{l}\text { Sample } \\
\text { Name }\end{array}$ & $\begin{array}{l}\text { Sample } \\
\text { weight } \\
\quad(g)\end{array}$ & $\begin{array}{l}\text { mass of Cl } \\
\text { in spike } \\
(\mathbf{m g})\end{array}$ & ${ }^{35} \mathrm{Cl} /{ }^{37} \mathrm{Cl}$ & ${ }^{36} \mathrm{Cl}^{35} \mathrm{Cl}\left(10^{-14}\right)$ & $\begin{array}{l}{[\mathrm{Cl}] \text { in }} \\
\text { sample } \\
(\mathrm{ppm})\end{array}$ & $\begin{array}{l}{\left[^{36} \mathrm{Cl}\right]\left(10^{3}\right.} \\
\left.\text { atoms } \mathrm{g}^{-1}\right)\end{array}$ & Age $(y r)^{a}$ & $\begin{array}{l}\text { Weighted mean } \\
\text { age (yr) }\end{array}$ \\
\hline \multicolumn{9}{|l|}{ M1 moraine } \\
\hline Ker-M1-01 ${ }^{\mathrm{b}}$ & 59.416 & 1.613 & $13.610 \pm 0.061$ & $0.78 \pm 0.12$ & 10.4 & $2.86 \pm 0.84$ & $560 \pm 200(200)$ & \multirow{6}{*}{$800 \pm 260(\mathbf{1 4 0})^{d}$} \\
\hline Ker-M1- $02^{b}$ & 62.178 & 1.598 & $56.01 \pm 0.31$ & $0.85 \pm 0.12$ & 1.6 & $2.27 \pm 0.66$ & $880 \pm 280(270)$ & \\
\hline Ker-M1-04 ${ }^{\mathrm{b}}$ & 55.147 & 1.616 & $8.536 \pm 0.042$ & $0.82 \pm 0.13$ & 22.2 & $4.5 \pm 1.1$ & $1020 \pm 320(310)$ & \\
\hline Ker-M1-0 $07^{\mathrm{b}}$ & 66.554 & 1.620 & $26.88 \pm 0.20$ & $0.68 \pm 0.11$ & 3.9 & $1.55 \pm 0.62$ & $350 \pm 160(160)$ & \\
\hline MO-18 & 69.670 & 2.006 & $4.53 \pm 0.23$ & $0.98 \pm 0.13$ & 84.3 & $15.2 \pm 3.0$ & $1700 \pm 440(410)$ & \\
\hline MO-19 & 64.240 & 2.012 & $10.37 \pm 0.44$ & $0.88 \pm 0.14$ & 17.3 & $6.5 \pm 1.1$ & $850 \pm 240(230)$ & \\
\hline \multicolumn{9}{|l|}{ M2 moraine } \\
\hline MO-14 & 83.100 & 2.002 & $4.10 \pm 0.10$ & $0.68 \pm 0.10$ & 101.9 & $11.5 \pm 3.7$ & $1030 \pm 580(570)$ & \multirow{3}{*}{$580 \pm 310(\mathbf{2 5 0})^{\mathrm{d}}$} \\
\hline MO-15 & 86.260 & 2.007 & $4.20 \pm 0.20$ & $0.76 \pm 0.10$ & 89.2 & $11.6 \pm 2.5$ & $790 \pm 340(330)$ & \\
\hline MO-16 & 82.710 & 2.007 & $26.1 \pm 1.2$ & $0.42 \pm 0.10$ & 3.9 & $1.83 \pm 0.48$ & $330 \pm 100(100)$ & \\
\hline Blanks $^{\mathrm{c}}$ & & & & & $\begin{array}{c}\text { Total atoms } \mathrm{Cl} \\
\quad\left(10^{17}\right)\end{array}$ & $\begin{array}{c}\text { Total atoms }{ }^{36} \mathrm{Cl} \\
\left(10^{4}\right)\end{array}$ & & \\
\hline Bk1 & - & 1.623 & $300.7 \pm 5.2$ & $0.395 \pm 0.081$ & $2.604 \pm 0.067$ & $17.4 \pm 2.9$ & - & - \\
\hline $\mathrm{Bk} 2$ & - & 1.610 & $261.5 \pm 3.0$ & $0.379 \pm 0.085$ & $3.164 \pm 0.051$ & $10.6 \pm 2.4$ & - & - \\
\hline Bk7 & - & 1.988 & $233.5 \pm 10.8$ & $0.037 \pm 0.019$ & $1.31 \pm 0.32$ & $12.7 \pm 6.4$ & - & - \\
\hline \multicolumn{9}{|c|}{$\begin{array}{l}\text { a Age uncertainties are reported at } 1 \text { sigma level and were calculated through full propagation of analytical and production rate errors. Numbers in brackets are analytical } \\
\text { uncertainties only. } \\
\text { b Samples from Jomelli et al. (2017) }\end{array}$} \\
\hline${ }^{c}$ Bkl was proces & t ith & 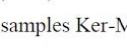 & A1-01, -04, -07. Bk2 & was processed with & the sample Ker-M & 11-02. All the other & he & \\
\hline${ }^{\mathrm{d}}$ Weighted error & & & & & & & & \\
\hline
\end{tabular}

Extent of the ice cap during the last millennium and associated climate scenario

During the beginning and middle of the last millennium, the CIC had a relatively large extent, as indicated by the mean ${ }^{36} \mathrm{Cl}$ ages of the dated M1 and M2 moraines, $1220 \pm 260 \mathrm{CE}$ and $1440 \pm$ $310 \mathrm{CE}$, respectively. The glacier re-advance that led to the formation of moraine M2 could be considered as representative of the early LIA in the islands, while moraine M1 was likely 
deposited at the beginning of the last millenium. As shown in Fig. 5a, we used the position of moraine M2 to constrain the simulated extent of the CIC during the early LIA advance using the glaciological model. 


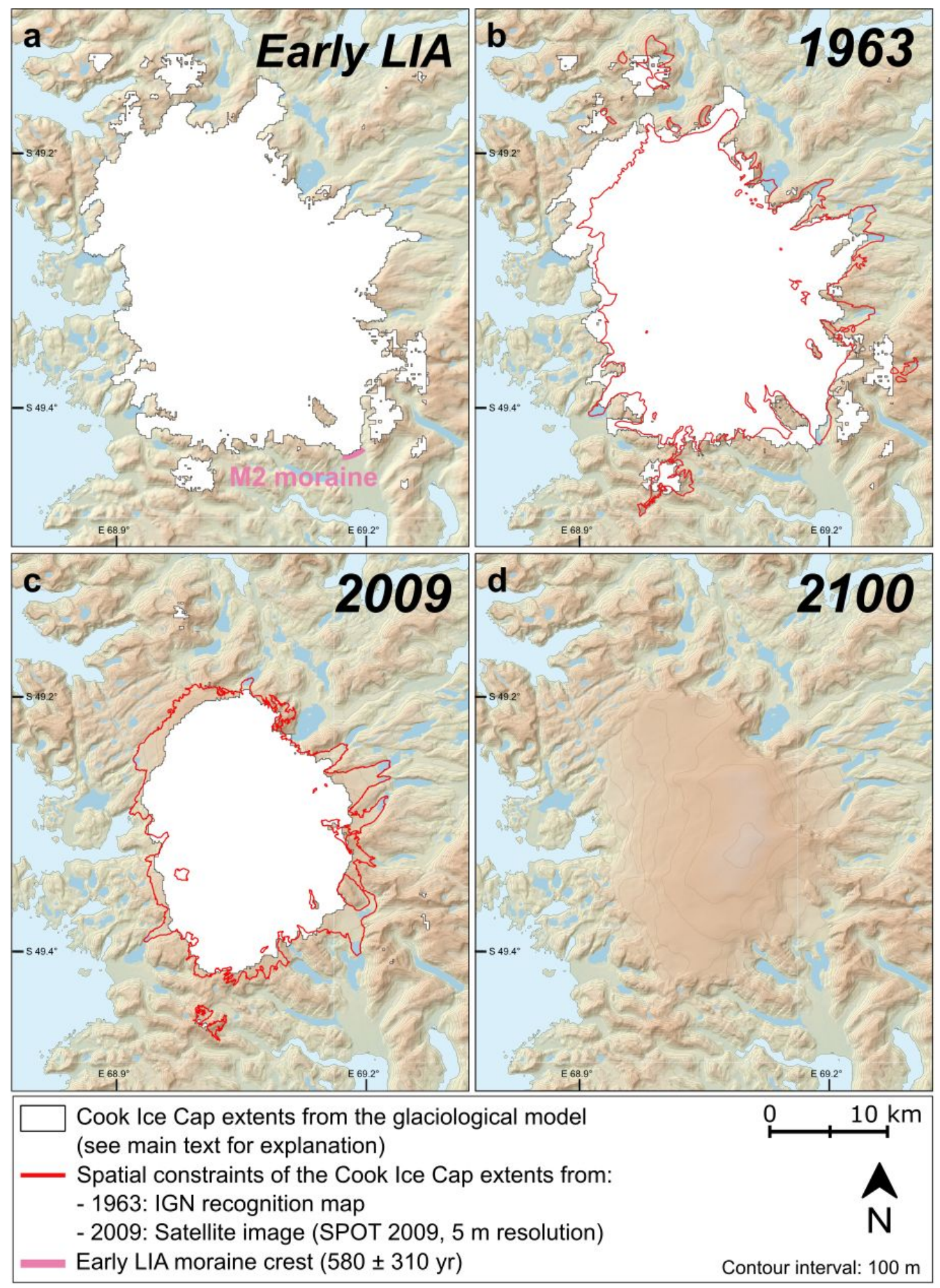

Fig. 5. Modelled extents of the CIC for the early LIA (a), 1963 (b), 2009 (c) and 2100 under the RCP8.5 scenario (d) from the glaciological model (see main text for explanation). The early LIA M2 moraine crest is represented in pink and spatial constraints for the CIC extents in 1963 and 2009 are represented by red contours. Digital Elevation Model from lpdaac.usgs.gov/products/srtmgl1v003/. 
Figures 5b and 5c and Table V show the simulated extents of the CIC in 1963 and 2009, respectively, in comparison with the spatial extents mapped from the IGN geological reconnaissance map and the 2009 SPOT satellite image, as well as the modelled ELAs. It can be noted that in 1963, the glaciological model overestimates the extent of the CIC, while in 2009, it underestimates it, especially at the location of Ampere Glacier and more generally for outlet glaciers on the eastern slope of the CIC. Between the early LIA and 1963, the CIC surface area loss based on the IGN map is estimated at about $-20 \%$, while the glaciological modelling indicates a CIC surface area loss of only about $-11 \%$. The modelled ELA slightly increased between the early LIA and 1963, evolving from $614 \mathrm{~m}$ a.s.1. to $638 \mathrm{~m}$ a.s.1. Since the $1970 \mathrm{~s}$, the ice cap has retreated dramatically, losing about -22\% of its surface area between 1963 and 2009 according to the IGN map and the 2009 satellite image, while the glaciological modelling suggests $-41 \%$ of area loss, assuming the modelled extent in 2009 represents a permanent regime (equilibrium state of the CIC). The modelled ELA increased markedly between 1963 and 2009, by about $170 \mathrm{~m}$ (from $638 \mathrm{~m}$ a.s.1. to $807 \mathrm{~m}$ a.s.1.). The differences between the ice extents derived from the historical documents and the glaciological modelling are analysed in the Discussion.

Table V - Comparison of modelled and observed glacial extents (in $\mathrm{km}^{2}$ ) of the CIC for the different periods analysed in this study. The modelled ELAs (in $m$ a.s.1.) are also given.

\begin{tabular}{lccccc}
\hline & Early LIA & $\mathbf{1 9 6 3}$ & $\mathbf{2 0 0 9}$ & $\mathbf{2 1 0 0}$ (RCP4.5) & $\mathbf{2 1 0 0}$ (RCP8.5) \\
\hline Modelled extent $\left(\mathbf{k m}^{2}\right)$ & 628.7 & 561.2 & 330.5 & 137.0 & 0 \\
Observed extent $\left(\mathbf{k m}^{2}\right)$ & - & 503.5 & 391.0 & - & - \\
Modelled ELA $(\mathbf{m}$ a.s.l.) & 614 & 638 & 807 & 938 & 1077 \\
\hline
\end{tabular}

Palaeo-climatic conditions of temperature and precipitation that best represent the location of early LIA moraine M2 according to the glaciological modelling were selected (Table VI). Based on a comparison with the ERSSTv2 sea surface temperature reconstruction for the 19th century, a temperature $0.17^{\circ} \mathrm{C}$ cooler on average compared to the reference period 1935-1962 (period of glacier stability, see the Methods section) was selected among the available potential scenarios. Once temperature was set, mean precipitation amounts similar to those measured over this 
reference period were needed to reproduce the extent of Ampere Glacier during the early LIA, corresponding to moraine M2. From 1963 to 2009 , temperature increased slightly $\left(+0.47^{\circ} \mathrm{C}\right)$, but the main contributor to the ice cap retreat was precipitation decrease. Observed precipitation decreased by 49\% between 1963 and 2009 (Table VI).

Table VI - Summary of the climatic scenarios of temperature and precipitation evolution between the early LIA (1440 $\pm 310 \mathrm{CE}$ ) and 1963 (corresponding to the reference period 1935-1962), 1963 and 2009 (corresponding to the period 2000-2010) and 2009 and 2100 (corresponding to the period 2090-2100) for the two RCPs. See the Methods section for details about the periods considered.

\begin{tabular}{|c|c|c|c|c|}
\hline & $\begin{array}{c}\text { Early LIA } \rightarrow 1963 \\
\text { modelled }\end{array}$ & $\begin{array}{c}1963 \rightarrow 2009 \\
\text { observed }\end{array}$ & $\begin{array}{c}2009 \rightarrow 2100(\text { RCP4.5) } \\
\text { modelled }\end{array}$ & $\begin{array}{c}2009 \rightarrow 2100(\text { RCP8.5) } \\
\text { modelled }\end{array}$ \\
\hline Temperature & $+0.17^{\circ} \mathrm{C}$ & $+0.47^{\circ} \mathrm{C}$ & $+1.0^{\circ} \mathrm{C}$ & $+2.3^{\circ} \mathrm{C}$ \\
\hline Precipitation & $0 \%$ & $-49 \%$ & $11 \%$ & $23 \%$ \\
\hline
\end{tabular}

Estimation of CIC extent in 2100 based on future climate scenarios

The simulated CIC extent for 2100 based on the glaciological model driven by the Australian ACCESS1-3 climate model is displayed in Fig. 5d and Table V. In this model, under the RCP4.5 (respectively, RCP8.5) scenario, future temperature in 2100 is expected to increase by $1.0^{\circ} \mathrm{C}$ $\left(2.3^{\circ} \mathrm{C}\right)$ compared to 2009 , while precipitation is predicted to increase by $\sim 11 \%(\sim 23 \%)$, as shown in Table VI. Based on the glaciological modelling, if the RCP4.5 scenario is considered, the CIC would be reduced to $\sim 137 \mathrm{~km}^{2}$, and the ELA would rise by $131 \mathrm{~m}$ (from $807 \mathrm{~m}$ a.s.1. to 938 m a.s.1.). Under the RCP8.5, the ice cap would completely disappear by 2100 . The modelled ELA would increase by $\sim 270 \mathrm{~m}$ (from $807 \mathrm{~m}$ a.s.1. to $1077 \mathrm{~m}$ a.s.1.), with an ELA above the summit of the CIC (1049 m a.s.1.) in 2100. Roughly, results indicate that mass balance values and ELA simulated for 2100 using RCP4.5 are comparable to the ones for 2050 using RCP8.5 (not shown).

As a sensitivity test, alternative hypotheses were tested, for example using precipitation values similar to those observed over the 2010 s (i.e. $50 \%$ higher than during the 2000 s) or over the 1950s (i.e. 100\% higher than during the 2000s). This allows analysing the behavior of the CIC if precipitation would increase strongly or very strongly in the future, respectively. Under RCP8.5, a strong increase in precipitation would lead to a decrease of about $83 \%$ in CIC extent between 
2009 and 2100 ( $85 \%$ if the observed extent in 2009 is considered), while a very strong increase in precipitation would lead to a $51 \%$ decrease (59\% respectively) in glacial extent (not shown).

\section{Discussion}

\section{The early LIA in the Kerguelen Islands}

Chlorine-36 CRE ages from moraine boulders collected on Ampere Glacier's proglacial margin provide evidence of several glacial advances that occurred during the last millennium. The first (oldest) advance is recorded by the outermost M1 moraine, dated at $800 \pm 260 \mathrm{yr}$ ago (1220 \pm $260 \mathrm{CE}$ ), and a subsequent advance led to the formation of M2 moraine, dated at $580 \pm 310 \mathrm{yr}$ ago (1440 $\pm 310 \mathrm{CE})$ (Fig. 4). At least four other younger moraines located upstream remain undated. Considering uncertainties ( $\pm 310 \mathrm{yr}$ for moraine M2), it is likely that the M2 glacial advance is linked with the global cold event of the early LIA. However, we do not rule out the possibility that the M2 moraine was deposited prior to the onset of the LIA, at the beginning of the last millennium ( 1100 CE), as observed in the Northern Hemisphere (Solomina et al., 2015). Similarly, the M1 moraine was likely deposited at the beginning of the last millenium, but, considering uncertainties ( $\pm 260 \mathrm{yr}$ for moraine M1), it may also have been deposited at the onset of the LIA.

Thus, in situ-produced ${ }^{36} \mathrm{Cl} \mathrm{CRE}$ dated moraines suggest a significant extension of the CIC beyond its present-day size during the early LIA (Figs. 4 and 5a). This is consistent with the general glacial advances (Solomina et al., 2015) widely observed in the Northern Hemisphere (e.g., Mann, 2002; Ivy-Ochs et al., 2009), but also in the Southern Hemisphere. In particular, larger-than-today glacial extensions have been identified in Patagonia (e.g., Reynhout et al., 2019) and New Zealand (Schaefer et al., 2009; Putnam et al., 2012) in the second half of the past millennium. However, geomorphological observations of these LIA glacial advances are scarce on the sub-Antarctic islands (e.g., Oppedal et al., 2018) because most glaciers were calving into the ocean at that time, leaving few datable terrestrial moraines. 
Contrary to the present-day, for which the SAM index is positive, a negative SAM index has been proposed for the period from $\sim 1400 \mathrm{CE}$ to $\sim 1600 \mathrm{CE}$ (Abram et al., 2014; Perren et al., 2020). A negative phase is expected to imply larger precipitation amounts and colder temperatures than during the reference period CE 1961-1990 in Abram et al. (2014). This is also confirmed by a recent study by Perren et al. (2020). Recent reconstructions of precipitation since the mid 19th century (Favier et al., 2016) also suggest that precipitation remained relatively stable before the recent increase in the SAM since the 1970s. Assuming that the SAM largely controls precipitation amounts on the Kerguelen Islands (as shown by Favier et al., 2016, Pohl et al., under review), negative SAM phases during the early LIA glacial advance recorded on the Kerguelen Islands likely induced precipitation amounts similar to those measured in the 1950s and 1960s, as inferred from the glaciological modelling. Palaeo-climatic conditions of glacial advances during the early LIA on the archipelago were also slightly colder during this period (about $-0.17^{\circ} \mathrm{C}$ ) compared to conditions that prevailed in 1963 (corresponding to the reference period 1935-1962). This provides complementary information to the only existing palae-oclimatic reconstruction produced for this sector of the Southern Ocean (Perren et al., 2020). It provides new insights into the climatic conditions associated with the early LIA in a region where climate models generally perform poorly over the recent period (e.g., Favier et al., 2016; Verfaillie et al., 2019). Similar to the findings of Reynhout et al. (2019) for Patagonia, our results suggest that climate and subsequent glacier evolution on the Kerguelen Islands over the last millennium was highly influenced by fluctuations in the SAM. The period between $\sim 1400$ and $\sim 1600 \mathrm{CE}$ corresponds to the period during which the SAM index was the most negative over the last millennium (Abram et al., 2014; Perren et al., 2020). This also suggests that past CIC wastage and extents reflected this extreme state of the SAM, making the Kerguelen Islands one of the best laboratories to study this most important climate feature at high latitudes in the Southern Hemisphere (as the leading empirical orthogonal function of extratropical atmospheric mode of variability in the Southern Hemisphere).

\section{Uncertainties in the glacio-climatic simulations}


To the first order, the simulated 1963 and 2009 extents fit relatively well with extents derived from the IGN geological reconnaissance map and the SPOT image, respectively (Figure 5). However, local discrepancies exist between the simulated extents and the observed ones in 1963 and 2009. In addition, the total extents from the glaciological model are $\sim 9 \%$ too large in 1963 and $\sim 19 \%$ too small in 2009 . Since the model was designed to represent permanent states of the CIC, it does not allow reproducing the exact timing of a transient glacier front retreat. The reduced size of the modelled (permanent) extent relative to observations in 2009 reflects the fact that the CIC is actually in a transitional regime. Differences between model results and observations also may result from (1) the too coarse resolution of the glaciological model (125 $\mathrm{m})$, (2) the extrapolation of meteorological data from PAF and (3) the simplicity of the glaciological model. Concerning the latter, we believe that the main uncertainty affecting the cellular automaton (dynamical part of the model) is related to the fact that the glacier model is applied on 2009's DEM and that the ice cap thickness and thus the depth of the ice cap bedrock remains unknown. We attempted some ground penetrating radar measurements on Ampere Glacier in 2014 to obtain more information on the bedrock depth, but were unsuccessful due to the high liquid content at the glacier surface and subsurface. In addition, we consider that, given the simplicity of the glacio-climatic model and the uncertainties in the parameters applied in the model, a resulting uncertainty in the order of $10-20 \%$ is acceptable. This study shows that the degree-day glaciological model combined with a cellular automaton is - although rather simple a robust tool given the spatio-temporal scales considered.

Concerning the simulated early LIA extent, it must be taken into account that the only moraines that are so-far dated to the last millennium are M1 and M2 in the Ampere valley, making the constraint for the whole Cook Ice Cap rather limited. Several other CIC outlet glaciers have deposited moraines that could potentially correspond to the LIA, but they remain undated. The simulated early LIA extents should therefore be considered with caution.

Concerning future extents, uncertainties also arise from the model and the climatic scenarios used to drive the glaciological model. Although ACCESS1-3 is the model that best simulates precipitation amounts and temperature over the recent period (Verfaillie et al., 2019), it is still 
affected by biases that needed to be accounted for in this study (see Methods section). Even after this bias correction, we had to make certain hypotheses concerning the future climate scenarios from ACCESS1-3. For instance, we considered that precipitation at the end of the century would moderately increase by $+11 \%$ under the RCP4.5 scenario and $+23 \%$ under RCP8.5 (Table VI) due to increasing temperature (Clausius-Clapeyron processes already taken into account in the ACCESS1-3 model). Considering alternative hypotheses on precipitation, i.e. a strong or very strong increase in precipitation by the end of the century, would still imply a reduction of $83 \%$ and 51\%, respectively, in CIC extent between 2009 and 2100.

Moreover, modelled extents are simulated by taking the CIC extent and topography at a given snapshot in time as a reference (using the DEM from 1963 for the early LIA and 1963 extents and the DEM from 2009 for the 2009 and 2100 extents). The ice cap elevation and extent are updated iteratively as the simulation runs, but the surface elevation never goes below the 2009 DEM elevation, whereas the glacier surface elevation will decrease as ice will disappear over time. This strong feedback on a negative surface mass balance is not taken into account in our glaciological projections, which adds another source of uncertainty to the simulated extents.

\section{Future evolution of the Cook Ice Cap}

We used the bias-corrected daily temperature and precipitation simulated for 2100 from a single model (ACCESS1-3) forced by the two available RCP scenarios (RCP4.5 and RCP8.5) to drive the glaciological model. Still, we showed above that the extent of CIC is expected to be reduced strongly or to have disappeared completely by 2100 , owing to the strong sensitivity of the CIC to climate fluctuations, for various geomorphological, glaciological and climatological reasons. Firstly, the accumulation area of the CIC is located at low altitudes (currently between $\sim 800 \mathrm{~m}$ and $1049 \mathrm{~m}$ a.s.1.). This is because the oceanic climate and the location of the Kerguelen Islands on the storm tracks' path supply sufficient moisture that results in significant snow accumulation on the ice cap. However, due to the recent dryness experienced at Kerguelen, linked to the SAM-induced shift of the storm tracks to more southerly latitudes, the accumulation area of the CIC should rapidly lose mass and disappear before the end of the century (Favier et al., 2016). The SAM is the first order variable that modulates daily regime occurrences and their seasonal 
frequencies throughout the year on the Kerguelen Islands (Pohl et al., under review). Its control on temperature and precipitation trends has also been demonstrated at the interannual timescale, with dramatic consequences on the glacier behaviour over the second half of the 20th century (Verfaillie et al., 2015; Favier et al., 2016). The future of the CIC will thus be strongly tied to the potential changes in the SAM phase.

Secondly, the hypsometry of the CIC (dome-shaped and almost flat between $\sim 600 \mathrm{~m}$ a.s.l. and its summit, see Fig. 5c in Verfaillie et al., 2015) plays an important role in the response of the net accumulation area to changes in temperature. Indeed, Verfaillie et al. (2015) showed that the ELA had risen about $100 \mathrm{~m}$ between 2001 and 2012, implying a reduction of the accumulation area ratio (AAR) of about $20 \%$ and a decrease of the accumulation area of about $90 \mathrm{~km}^{2}$ (as a comparison, the total area of CIC in 2020 is about $400 \mathrm{~km}^{2}$ ). These values are conservative, as they apply for the recent period, but are expected to be even larger for the future. Indeed, as the CIC recedes, the ELA should reach higher altitudes where the surface is flatter, thereby uncovering larger areas. Based on the RCP8.5 scenario, our glaciological modelling foresees an ELA above the summit of the ice cap by 2100 , which would imply the complete disappearance of the CIC by the end of the century.

Thirdly, the increase in temperature will induce an increase in the altitude of the rain/snow transition, which will also have a detrimental impact on the accumulation area of the ice cap. Additionally, as shown by Verfaillie et al. (2015), it will reduce the surface albedo, resulting in a positive feedback on melt rates and the snow line elevation (Fig. 6) mainly through the shortwave radiation budget of the CIC. Given the extent and ELA simulated for 2100 and the sensitivity of the CIC to climate fluctuations explained above, we expect the ice cap to have completely disappeared by the end of the century. 

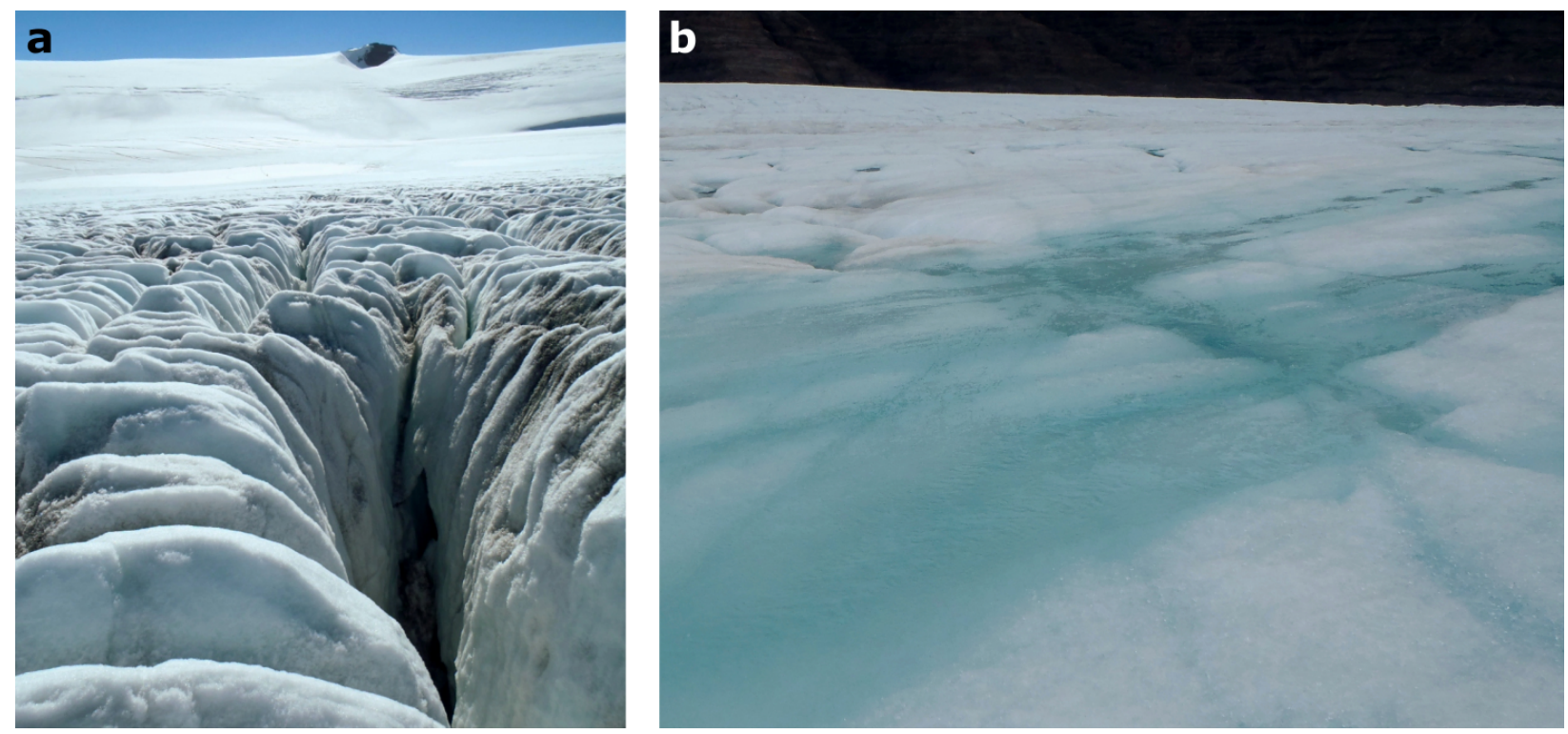

Fig. 6. Photographs of the surface of Ampere Glacier in January 2012. a. Crevassed ablation area at the forefront ( $\sim 550 \mathrm{~m}$ a.s.1.) and firn- and snow-covered accumulation area in the background ( $\sim 650 \mathrm{~m}$ a.s.1.). b. Surface melt in the ablation area ( $200 \mathrm{~m}$ a.s.1.).

\section{Conclusions}

To conclude, in this study, we have used glacio-climatic modelling and cosmogenic dating to assess the glacial evolution of the Cook Ice Cap in the sub-Antarctic Kerguelen Islands between the last centuries and the end of the 21 st century. Glacial extents for four snapshots in time were reconstructed, namely the first part of the Little Ice Age (commonly defined over the period 1400-1870 CE), 1963, 2009 and 2100, and their associated climatic scenarios revealed.

Despite large uncertainties, ${ }^{36} \mathrm{Cl}$ cosmogenic nuclide dating of morainic boulders from Ampere valley reveals two consecutive glacial advances that most likely occurred during the early LIA. The oldest advance, recorded by the outermost M1 moraine, was dated at $800 \pm 260 \mathrm{yr}$ ago (1220 $\pm 260 \mathrm{CE}$ ), and a subsequent advance or stillstand led to the formation of M2 moraine, dated at $580 \pm 310$ yr ago $(1440 \pm 310 \mathrm{CE})$. Geomorphological evidence of past glaciations is scarce on the sub-Antarctic islands, and this is the first time that moraines from this period are dated in the Indian sector of the Southern Ocean, thereby contributing to our currently limited understanding of palaeoclimate for the early LIA in this region. It brings new insights into the climatic 
conditions (cold and humid compared to today) associated with the LIA in a region where climate models generally perform poorly over the recent period. For the recent period (between 1963 and 2009), glaciological modelling and observations show a rather strong decrease in the CIC extent, associated with an increase in the Equilibrium Line Altitude. Similar to studies in Patagonia, our results suggest that climate and subsequent glacier evolution on the Kerguelen Islands over the last millennium was highly influenced by fluctuations in the Southern Annular Mode, one of the most important climate features at high latitudes of the Southern Hemisphere. This also suggests that past CIC wastage and extents reflected the state of the SAM, making the Kerguelen Islands one of the best laboratories to study this prominent feature of the climate system.

Concerning uncertainties affecting the glaciological modelling, we have shown that local discrepancies exist between the simulated extents and the observed ones, mainly due to the unknown depth of the bedrock below the ice cap. For future extents, uncertainties also arise from the climate model used as an input of the glaciological model. We used bias-corrected fields of temperature and precipitation from the Australian ACCESS1-3 model, the model that, according to previous studies, performs the best over our region for the recent period. Despite a large variability in projected temperature in CMIP5 models, all the models project a dramatic warming in the area, generally leading to a rise of the ELA above the summit of CIC. The behaviour of ACCESS1-3, being very close from the "mean model", represents the most likely projection for the RCP8.5 scenario. Because warming will rapidly become the main cause of CIC wastage, getting more reduced emissions in greenhouse gases would clearly limit the acceleration in the disappearance of the CIC. Nevertheless, for the RCP8.5 scenario, even with a strong increase in precipitation by 2100 , the CIC extent would still be reduced by more than half compared to 2009, and the ELA be confined to the last tens of meters from the summit. Considering these uncertainties and the strong sensitivity of the ice cap to climate fluctuations, we expect the CIC to have completely disappeared by the end of the century. Future studies should assess the timing of this disappearance in more detail, for example by quantifying the different contributors to the elevation feedback. 


\section{Acknowledgements}

This work has received financial support from the LabEx DynamiTe (ANR-11-LABX-0046) Les Envahisseurs, as part of the "Investissements d'Avenir" program. This paper was also supported by the French INSU LEFE Glacepreker project and by the IPEV Kesaaco 1048 project. Logistical supply to the Kerguelen Islands was provided by the French Polar Institute. The ${ }^{36} \mathrm{Cl}$ measurements were performed at the ASTER AMS national facility (CEREGE, Aix-en-Provence) that is supported by the INSU/CNRS, the ANR through the "Projets thématiques d'excellence" program for the "Equipements d'excellence" ASTER-CEREGE action and IRD. We thank Météo France for the meteorological data from Port-aux-Français. We acknowledge the World Climate Research Program's Working Group on Coupled Modelling, which is responsible for CMIP, and we thank the Commonwealth Scientific and Industrial Research Organisation and Bureau of Meteorology for producing and making available the ACCESS1-3 model outputs. EB acknowledges support from the French Space Agency (CNES). Finally, we thank two anonymous reviewers for their useful comments and suggestions.

\section{Author contributions}

VJ, VR, CL, VF and DV conducted the fieldwork on the islands. VF modelled the ice cap extents. JCh and IS produced the cosmogenic data. GA, DLB and KK (ASTER Team) performed accelerator mass spectrometry measurements. JCh, IS and VJ interpreted the cosmogenic ages. $\mathrm{ZS}, \mathrm{JCa}, \mathrm{EB}$ and RC produced the cartographic data. JCh, DV and FB prepared the figures. DV, JCh, IS, ZS, VJ, FB, VF, JCa, EB and HG wrote the paper. All authors have approved the contents of the manuscript.

\section{Details of data deposit}


The ${ }^{36} \mathrm{Cl}$ data will be found on an open access repository on the informal cosmogenic-nuclide exposure-age database (ICE-D: Alpine; http://alpine.ice-d.org/). Meteorological data from the weather stations used in this study can be found on the following repository: http://pp.ige-grenoble.fr/pageperso/faviervi/kesaaco/AWS.php.

\section{References $(\max 40)$}

Abram, N.J., Mulvaney, R., Vimeux, F., Phipps, S.J., Turner, J. \& England, M.H. 2014. Evolution of the Southern Annular Mode during the past millennium. Nature Climate Change, 4 , 564-569, 10.1038/nclimate2235.

Aubert de la Rüe, E. 1932. Étude géologique et géographique de l'archipel de Kerguelen. Revue de géographie physique et de géologie dynamique, 5, 1-231.

Aubert de la Rüe, E. 1967. Remarques sur la disparition des glaciers de la Péninsule Courbet (Archipel de Kerguelen). Terres Australes et Antarctiques Françaises, 40, 3-20.

Ballestracci, R. \& Nougier, J. 1984. Detection by infrared thermography and modelling of an icecapped geothermal system in Kerguelen Archipelago. Journal of Volcanology and Geothermal Research, 20(1-2), 85-100, 10.1016/0377-0273(84)90067-2.

Berthier, E., Le Bris, R., Mabileau, L., Testut, L. \& Rémy, F. 2009. Ice wastage on the Kerguelen Islands $\left(49^{\circ} \mathrm{S}, 69^{\circ} \mathrm{E}\right)$ between 1963 and 2006. Journal of Geophysical Research, 114, 20 p., 10.1029/2008JF001192.

Biette, M., Jomelli, V., Favier, V., Chenet, M., Agosta, C., Fettweiss, X., Ho Tong Minh, D. \& Ose, K. 2018. Estimation des températures au début du dernier millénaire dans l'ouest du Groenland : Résultats préliminaires issus de l'application d'un modèle glaciologique de type 
degré jour sur le glacier Lyngmarksbræen. Géomorphologie, 24, 31-41, 10.4000/geomorphologie.11977.

Blard, P.H., Lave, J., Pik, R., Wagnon, P. \& Bourles, D. 2007. Persistence of full glacial conditions in the central Pacific until 15,000 years ago. Nature, 449, 591-594, 10.1038 /nature 06142 .

Chapui, J.-L., Frenot, Y. \& Lebouvier, M. 2004. Recovery of native plant communities after eradication of rabbits from the subantarctic Kerguelen Islands, and influence of climate change. Biological Conservation, 117(2), 167-179, 10.1016/S0006-3207(03)00290-8.

Charton, J., Jomelli, V., Schimmelpfennig, I., Verfaillie, D., Favier, V., Mokadem, F., Gilbert, A., Brun, F., Aumaître, G., Bourlès, D.L. \& Keddadouche, K. 2020. A debris-covered glacier at Kerguelen $\left(49^{\circ} \mathrm{S}, 69^{\circ} \mathrm{E}\right)$ over the past 15,000 years. Antarctic Science, 1-13, $10.1017 / \mathrm{S} 0954102020000541$.

Durand de Corbiac, H. 1970. La carte de reconnaissance des îles Kerguelen. Bulletin du Comité National Français des Recherches Antarctiques, 26, 1-73.

Favier, V., Verfaillie, D., Berthier, E., Menegoz, M., Jomelli, V., Kay, J.E., Ducret, L., Malbéteau, Y., Brunstein, D., Gallée, H., Park, Y.-H. \& Rinterknecht, V. 2016. Atmospheric drying as the main driver of dramatic glacier wastage in the southern Indian Ocean. Scientific Reports, 6, 32396, 10.1038/srep32396.

Frenot, Y., Gloaguen, J.C., Picot, G., Bougère, J. \& Benjamin, D. 1993. Azorella selago Hook. used to estimate glacier fluctuations and climatic history in the Kerguelen Islands over the last two centuries. Oecologia, 95, 140-144, 10.1007/BF00649517.

Frenot, Y., Gloaguen, J.-C., van de Vijver, B. \& Beyens, L. 1997. Datation of some Holocene peat sediments and glacier fluctuations in the Kerguelen Islands. Comptes Rendus Académie Sciences Série III-Sci. Vie - Life Sci., 320(7), 567-573. 
Frenot, Y., Chown, S.L., Whinam, J., Selkirk, P.M., Convey, P., Skotnicki, M. \& Bergstrom, D.M. 2005. Biological invasions in the Antarctic: extent, impacts and implications. Biological Reviews, 80, 45-72, 10.1017/S1464793104006542.

Ivy-Ochs, S., Kerschner, H., Maisch, M., Christl, M., Kubik, P.W. \& Schlüchter, C. 2009. Latest Pleistocene and Holocene glacier variations in the European Alps. Quaternary Science Reviews, 28(21-22), 2137-2149, 10.1016/j.quascirev.2009.03.009.

Jomelli, V., Khodri, M., Favier, V., Brunstein, D., Ledru, M.P., Wagnon, P., Blard, P.H., Sicart, J.E., Braucher, R., Grancher, D., Bourlès, D., Braconnot, P. \& Vuille, M. 2011. Irregular tropical glacial retreat during the Holocene driven by progressive warming. Nature, 474, 196-199, $10.1038 /$ nature 10150 .

Jomelli, V., Mokadem, F., Schimmelpfennig, I., Chapron, E., Rinterknecht, V., Favier, V., Verfaillie, D., Brunstein, D., Legentil, C., Michel, E., Swingedouw, D., Jaoen, A., Aumaître, G., Bourles, D.L. \& Keddadouche, K. 2017. Sub-Antarctic glacier extensions in the Kerguelen region $\left(49^{\circ} \mathrm{S}\right.$, Indian Ocean) over the past 23000 years constrained by ${ }^{36} \mathrm{Cl}$ moraine dating. Quaternary Science Reviews, 162, 128-144, 10.1016/j.quascirev.2017.03.010.

Krinner, G. \& Flanner, M. 2018. Striking stationarity of large-scale climate model bias patterns under strong climate change. Proceedings of the National Academy of Sciences of the United States of America, 115(38), 9462-9466, 10.1073/pnas.1807912115.

Lesel, R. 1967. Contribution à l'étude écologique de quelques mammifères importés aux îles Kerguelen. Terres Australes et Antarctiques Françaises, 38, 3-40.

Mann, M.E. 2002. Little Ice Age. In Encyclopedia of Global Environmental Change, edited by M.C. MacCracken, and J.S. Perry, Volume 1, The Earth system: physical and chemical dimensions of global environmental change, pp. 504-509, John Wiley, Chichester, U.K., ISBN 0-471-97796-9. 
Moss, R.H., Edmonds, J.A., Hibbard, K.A., Manning, M.R., Rose, S.K., Van Vuuren, D.P., Carter, T.R., Emori, S., Kainuma, M., Kram, T., Meehl, G.A., Mitchell, J.F.B., Nakicenovic, N., Ri-ahi, K., Smith, S.J., Stouffer, R.J., Thomson, A.M., Weyant, J.P. \& Wilbanks, T.J. 2010. The next generation of scenarios for climate change research and assessment. Nature, 463, 747-756, 10.1038 /nature 08823 .

Neukom, R., Gergis, J., Karoly, D., Wanner, H., Curran, M., Elbert, J., González-Rouco, F., Linsley, B., Moy, A., Mundo, I., Raible, C., Steig, E., van Ommen, T., Vance, T., Villalba, R., Zinke, J. \& Frank, D. 2014. Inter-hemispheric temperature variability over the last millennium. Nature Climate Change, 4, 362-367, 10.1038/nclimate2174.

Nougier, J. 1970. Contribution à l'étude géologique et géomorphologique des îles Kerguelen. PhD Thesis, Ed. CNFRA, Paris, 2e édition, 2 vol., 441 p. and 247 p. +1 inset map.

Perren, B.B., Hodgson, D.A., Roberts, S.J., Sime, L., Van Nieuwenhuyze, W., Verleyen, E., \& Vyverman, W. 2020. Southward migration of the Southern Hemisphere westerly winds corresponds with warming climate over centennial timescales. Communications Earth \& Environment, 1, 58, 10.1038/s43247-020-00059-6.

Oppedal, L.T., Bakke, J., Paasche, Ø., Werner, J.P., van der Bilt, W.G.M. 2018. Cirque glacier on South Georgia shows centennial variability over the last 7000 years. Frontiers in Earth Science, 6, 2, 10.3389/feart.2018.00002.

Poggi, A. 1977. Heat balance in ablation area of Ampere Glacier (Kerguelen Islands). Journal of Applied Meteorology Climatology, and 16, 48-55, 10.1175/1520-0450(1977)016<0048:HBITAA>2.0.CO;2.

Pohl, B., Saucède, T., Favier, V., Pergaud, J., Verfaillie, D., Féral, J.-P., Krasniqi, Y. \& Richard, Y., under review. Recent climate variability around the Kerguelen Islands (Southern Ocean) seen through weather regimes. Journal of Applied Meteorology and Climatology, under review. 
Protin, M., Schimmelpfennig, I., Mugnier, J.-L., Ravanel, L., Le Roy, M., Deline, P., Favier, V., Buoncristiani, J.-F., Aumaître, G., Bourlès, D.L. \& Keddadouche, K. 2019. Climatic reconstruction for the Younger Dryas/Early Holocene transition and the Little Ice Age based on paleo-extents of Argentière glacier (French Alps). Quaternary Science Reviews, 221, 105863, 10.1016/j.quascirev.2019.105863.

Putnam, A., Schaefer, J., Denton, G., Barrell, D.J.A., Finkel, R.C., Andersen, B.G., Schwartz, R., Chinn, T.J.H. \& Doughty, A.M. 2013. Regional climate control of glaciers in New Zealand and Europe during the pre-industrial Holocene. Nature Geoscience, 5, 627-630, 10.1038/ngeo1548.

Raup, B.H., Racoviteanu, A., Khalsa, S.J.S., Helm, C., Armstrong, R. \& Arnaud, Y. 2007. The GLIMS geospatial glacier database: a new tool for studying glacier change. Global and Planetary Change, 56, 101-110, 10.1016/j.gloplacha.2006.07.018.

Reynhout, S.A., Sagredo, E.A., Kaplan, M.R., Aravena, J.C., Martini, M.A., Moreno, P.I., Rojas, M., Schwartz, R. \& Schaefer, J.M. 2019. Holocene glacier fluctuations in Patagonia are modulated by summer insolation intensity and paced by Southern Annular Mode-like variability. Quaternary Science Reviews, 220, 178-187, 10.1016/j.quascirev.2019.05.029.

Schaefer, J.M., Denton, G.H., Kaplan, M., Putnam, A., Finkel, R.C., Barrell, D.J.A., Andersen, B.G., Schwartz, R., Mackintosh, A., Chinn, T. \& Schlüchter, C. 2009. High-frequency Holocene glacier fluctuations in New Zealand differ from the northern signature. Science, 324(5927), 622-625, 10.1126/science.1169312.

Schimmelpfennig, I., Schaefer, J.M., Akçar, N., Koffman, T., Ivy-Ochs, S., Schwartz, R., Finkel, R.C., Zimmerman, S. \& Schlüchter, C. 2014. A chronology of Holocene and Little Ice Age glacier culminations of the Steingletscher, Central Alps, Switzerland, based on high-sensitivity beryllium-10 moraine dating. Earth and Planetary Science Letters, 393, 220-230, 10.1016/j.eps1.2014.02.046. 
Smith, T.M. \& Reynolds, R.W. 2004. Improved extended reconstruction of SST (1854-1997). Journal of Climate, 17, 2466-2477, 10.1175/1520-0442(2004)017<2466:IEROS>2.0.CO;2.

Solomina, O.N., Bradley, R.S., Hodgson, D.A., Ivy-Ochs, S., Jomelli, V., Mackintosh, A.N., Nesje, A., Owen, L.A., Wanner, H., Wiles, G.C. \& Young, N.E. 2015. Holocene glacier fluctuations. Quaternary Science Reviews, 111, 9-34, 10.1016/j.quascirev.2014.11.018.

Taylor, K., Stouffer, R. \& Meehl, G. 2012. An overview of CMIP5 and the experiment design. Bulletin of the American Meteorological Society, 93(4), 485-498, 10.1175/BAMS-D-11-00094.1.

Vallon, M. 1977a. Bilan de masse et fluctuations récentes du Glacier Ampère (Iles Kerguelen, TAAF). Zeitschrift für Gletscherkunde und Glazialgeologie, 13, 55-85.

Vallon, M. 1977b. Topographie sous glaciaire du Glacier Ampère (Iles Kerguelen, TAAF). Zeitschrift für Gletscherkunde und Glazialgeologie, 13, 37-55.

Verfaillie, D., Favier, V., Dumont, M., Jomelli, V., Gilbert, A., Brunstein, D., Gallée, H., Rinterknecht, V., Menegoz, M. \& Frenot, Y. 2015. Recent glacier decline in the Kerguelen Islands $\left(49^{\circ} \mathrm{S}, 69^{\circ} \mathrm{E}\right)$ derived from modeling, field observations, and satellite data. Journal of Geophysical Research Earth Surface, 120(3), 637-654, 10.1002/2014JF003329.

Verfaillie, D., Favier, V., Gallée, H., Fettweis, X., Agosta, C. \& Jomelli, V. 2019. Regional modeling of surface mass balance on the Cook Ice Cap, Kerguelen Islands $\left(49^{\circ} \mathrm{S}, 69^{\circ} \mathrm{E}\right)$. Climate Dynamics, 53, 5909-5925, 10.1007/s00382-019-04904-z. 